\title{
千鳥配列された水平加熱円柱群の自然対流熱伝達
}

\author{
北村 健三*1，光石 暁彦 ${ }^{* 1}$, 鈴木 孝司 ${ }^{* 1}$
}

\section{Natural convective heat transfer from staggered banks of horizontal cylinders}

\author{
Kenzo KITAMURA ${ }^{* 1}$, Akihiko MITSUISHI ${ }^{* 1}$ and Takashi SUZUKI ${ }^{* 1}$ \\ ${ }^{* 1}$ Department of Mechanical Engineering, Toyohashi University of Technology \\ 1-1 Hibarigaoka, Tempaku-cho, Toyohashi-shi, Aichi 441-8580 Japan
}

Received: 18 April 2018; Revised: 8 July 2018; Accepted: 31 October 2018

\begin{abstract}
Natural convective heat transfer from staggered banks of horizontal cylinders to air was investigated experimentally. The experiments were mainly carried out with the banks consisted of five horizontal rows having nine and ten cylinders. The whole cylinders in the bank were heated with identical heat flux and their diameter $d$, vertical and horizontal gaps $G_{h}, G_{v}$ between cylinders were varied as $d=8.4,14.4 \mathrm{~mm}, G_{h}=10.6-30.6 \mathrm{~mm}$ and $G_{v}=5.6-30.6 \mathrm{~mm}$. The flow induced in the banks was first visualized with smoke and the Nusselt numbers of the whole cylinders in the banks were subsequently measured. The visual results depicted that the smokes issued from the bottom horizontal row of cylinders gather toward the vertical centerline of the bank. With the gathering of the plumes, the Nusselt numbers of the cylinders showed gradual reduction toward downstream. Their Nusselt numbers were next arranged with non-dimensional parameters to obtain heat transfer correlations. The result showed that the Nusselt numbers $N u_{G v}$ based on the vertical gaps $G_{v}$ between cylinders are correlated well with the parameter $\left[R a_{G v}{ }^{*}\left(G_{v} / d\right)^{2}\right]$ for the bottom row, while those for the central cylinders in the second to fifth rows are predicted well with the parameter $\left[R a_{G v}{ }^{*}\left(G_{v} / d\right)\left(G_{h} / d\right)\right]$, where $R a_{G v}{ }^{*}$ and $\left(G_{v} / d\right),\left(G_{h} / d\right)$ stand for the modified Rayleigh numbers based on the vertical gaps $G_{v}$ and the ratios of vertical and horizontal gaps to the cylinder diameter, respectively.
\end{abstract}

Keywords: Heat transfer, Natural convection, Horizontal cylinders, Tube banks, Heat exchangers

\section{1. 緒言}

加熱あるいは冷却された円柱が流れに平行および直交した方向に一定な間隔で多列・多段に配置された体系は チューブバンクとも呼ばれ，熱交換器やボイラを始めとする様々な伝熱機器，装置などでみられる体系である. このチューブバンクが一様な強制対流中に設置された場合の伝熱・流動特性に関しては，今まで数多くの実験や 解析が試みられ，バンクの伝熱性能や圧力損失を予測する相関式等が種々提案されている. 一方，チューブバン クが周囲流体と異なる温度に加熱・冷却され，バンクまわりに誘起された自然対流により周囲流体との間で熱移 動が生じる体系については，例えば冷暖房用のラジエータやピンフィン型ヒートシンクあるいは高レベル放射性 廃棄物の長期冷却保存など様々な機器, 装置などで見られる体系であるが, 自然対流下におけるバンクの伝熱・ 流動を取り扱った研究は，著者らが調査した限りでは，ごくわずかな数の研究が行われているに過ぎない.

それらの研究として，Bejan らによる解析(Bejan et al., 1995)と服部らによる実験(服部他, 1993 およ゙ 服部,相原, 1995)が挙げられる.これらの研究はいずれも常温の空気 $(P r=0.72)$ を試験流体としたものである.まず，Bejan ら

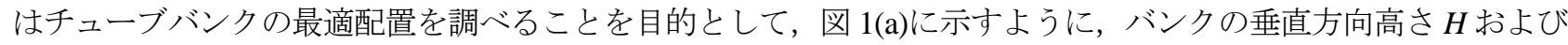

\footnotetext{
No.18-00194 [DOI:10.1299/transjsme.18-00194], J-STAGE Advance Publication date : 9 November, 2018

*1 正員, 豊橋技術科学大学大学院 機械工学専攻（广441-8580 愛知県豊橋市天伯町雲雀ヶ丘 1-1)

E-mail of corresponding author: kitamura@me.tut.ac.jp
} 
水平方向幅 $W$ が与えられた 2 次元空間中に，等温加熱された円柱が水平・垂直方向に同じ間隔 $G$ で千鳥配列さ れたバンクまわりの自然対流について, 有限要素法を用いた数值解析を行っている. 彼らの解析では, 図中斜線 で示寸計算領域を設定し，この領域の左右垂直境界で流れおよび温度場が対称となる，いわゆる周期境界条件を 課している. そして，この解析結果を基に計算領域内に存在する円柱列の放熱量を計算し，この放熱量を極大と 寸る円柱間隔 $G_{\mathrm{opt}}$ を求めている. しかし，彼らが解析で仮定した周期境界条件が現実のチューブバンクで成立す るか不明である.また，個々の円柱のヌセルト数等の解析結果は全く示されておらず，バンクの伝熱特性を詳し く議論するには至っていない.

一方，服部らは，常温空気中に直径 $d=25.4 \mathrm{~mm}$ の等温加熱円柱を，図 1(b) に示寸ように 5 列 $\times 5$ 段で格子状に 配列したチューブバンクを対象に, 図中 $\square$ で囲ったバンク中央の垂直円柱列について円柱のヌセルト数 $N u_{d}$ を測 定している. その結果, 最下段円柱の $N u_{d}$ は単独円柱のヌセルト数より高い值を示すこと, また 2 段目以降の円 柱のヌセルト数 $N u_{d}$ は垂直方向の円柱間隔が狭い $\left(P_{v} / d\right)=2$ の場合には, 下流に向かって低下寸るのに対して, $\left(P_{v}\right.$ $(d)=4$ では流れ方向にほぼ一定な值を示し， $\left(P_{v} / d\right)=8$ では下流に向かって増加する結果を得ている. ここで， $\left(P_{v}\right.$ ld ) は垂直方向の円柱中心間間隔 $P_{v}$ と円柱直径 $d$ の比を表す. また, 彼らは 5 本の垂直円柱列の平均熱伝達率 $\tilde{h}$ から円柱の水平方向間隔 $P_{h}$ を代表長さとするヌセルト数 $N u_{P h}\left(=\tilde{h} P_{h} / \lambda\right)$ を求め, このヌセルト数 $N u_{P h}$ が $G r_{P h}$ $\times\left(P_{h} / H\right) \times\left(P_{v} / d\right)^{1.38}$ なるパラメータで整理できることを報告している. ここで $G r_{P h}$ は円柱の水平方向間隔 $P_{h}$ を代 表長さとするグラスホフ数 $G r_{P h}\left(=g \beta \Delta T P_{h}{ }^{3} N^{2}\right), H$ は図に示寸円柱列の高さである. また, 服部, 相原(1995)は上 述の試験円柱を図 1(c)に示寸ように水平方向に 3 ないし 4 本, 垂直方向に 7 段千鳥配列したチューブバンクにつ いて, 図中濃灰色で示した 7 本の円柱のヌセルト数 $N u_{d}$ を測定している. 彼らは 7 本の円柱の平均熱伝達率 $\tilde{h}$ から水平方向の円柱間隔 $P_{h}$ を代表長さと寸る又セルト数 $N u_{P h}$ を求め, このヌセルト数 $N u_{P h}$ が前述の格子配列バ ンクとほぼ同様なパラメータ $G r_{P h} \times\left(P_{h} / H\right) \times\left(P_{v} / d\right)^{1.59}$ で整理できることを報告している. しかし，これら服部らの $2 つ の$ 実験では, 特定の本数および段数からなるチューブバンクの中心付近に設置された垂直円柱列の熱伝達率 が調べられているだけで，バンクを構成する他の円柱の伝熱特性は不明のままである，また，彼らが得た結果が 本数や段数が異なる他のバンクにも適用できるか不明である.

ところで，これらチューブバンクの自然対流伝熱を取り扱うには，まずチューブバンク内にどのような流れが 生じるか理解しておくことが必要不可欠と思われる. しかし, 従来の研究ではバンク内の流動を把握しないまま, 解析や実験を行っているのが実情である. また, バンクの伝熱特性は, バンクを構成する円柱の直径, 加熱量, 水平および垂直方向の円柱間隔, 円柱の水平方向の本数や垂直方向の段数など非常に多くのパラメータに依存し て変化し，さらには円柱がバンク内のどの位置に設置されるかによっても大きく変化すると考えられるが，これ らパラメータがバンクの伝熱に如何なる影響を及ぼすか，今まで詳しく検討した例はなく不明のままである.

このことから著者らは, 常温空気中に水平加熱円柱を図 2 に示すように 10 本 $\times 5$ 段で格子状に配列したチュー ブバンクを対象に，バンク内に生じる流れを可視化により調ベてみた(北村他, 2018). また， バンクを構成する円 柱の直径 $d$, 加熱量 $q_{j}$, 水平および垂直方向間隔 $G_{h}, G_{v}$ さらには円柱の水平方向の本数および垂直方向の段数を 系統的に変化させた場合について, バンクを構成する全ての円柱の熱伝達率 $h$ を測定し, これらパラメータが

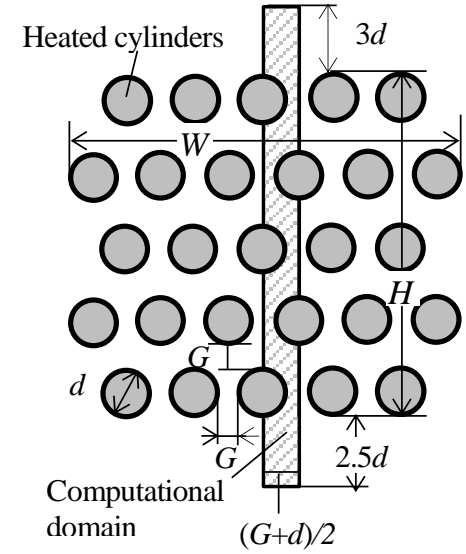

(a) Configuration of analysis by Bejan, et al. (1995)

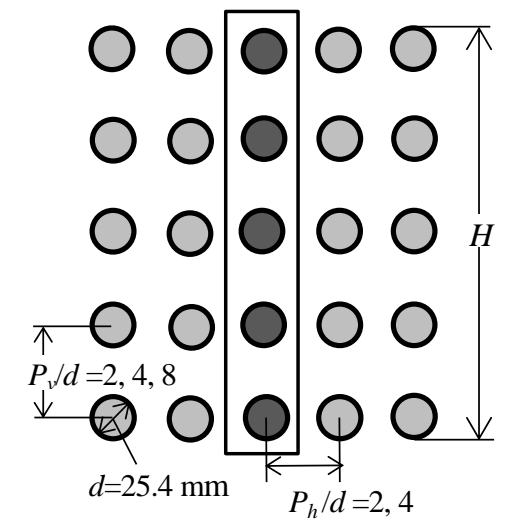

(b) Configuration of experiment by Hattori, et al. (1993)

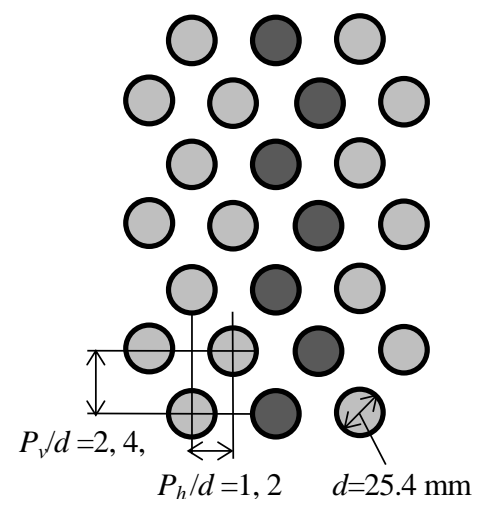

(c) Configuration of experiment by Hattori and Aihara. (1995)

Fig.1 Configurations and notations of previous studies on the tube banks. 


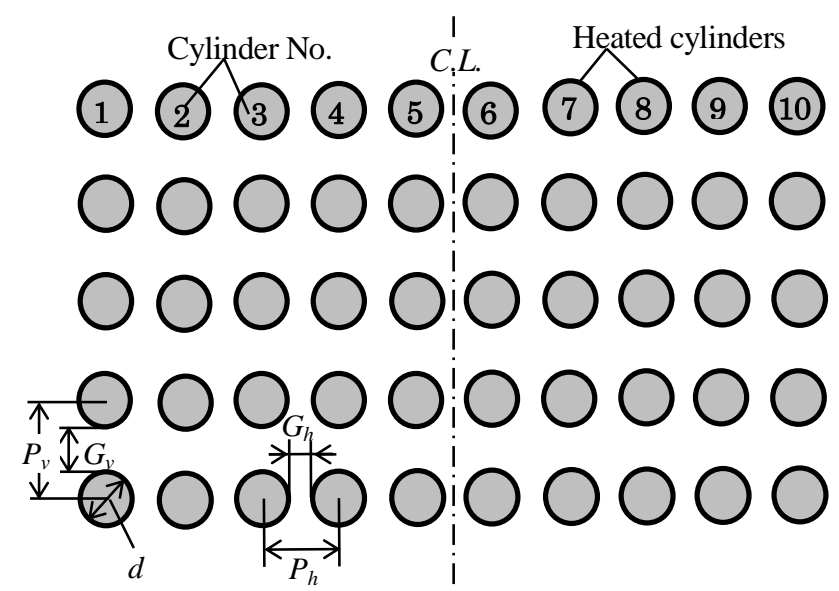

Fig.2 Configuration and notations of previous study on inline tube bank.

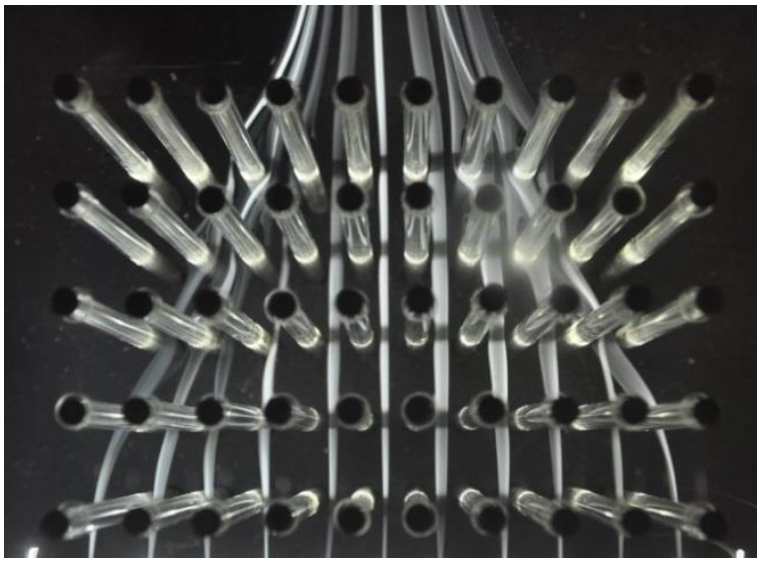

Fig.3Visualized flow field in the inline tube bank, $d=8.4 \mathrm{~mm}$, $G_{h}=10.6 \mathrm{~mm}, G_{v}=20.6 \mathrm{~mm}, q_{w}=185 \mathrm{~W} / \mathrm{m}^{2}, R a_{d}{ }^{*}=2.6 \times 10^{3}$.

円柱の伝熱特性に如何なる影響を及ぼすか調べた。そのうちバンク内の流れを煙により可視化した代表的な結果 を図 3 に示寸．この可視化に当たっては，バンク下方に内径 $2 \mathrm{~mm}$ のステンレスパイプを一定の水平方向間隔で 設置し，パイプから煙を鉛直上方に吐出させた．図３より，煙はバンクの中心付近では鉛直上方に流れるが，端 部付近ではバンク中心線に向かって寄り集まる様子が読み取れる.この可視化結果から, バンク内の流れは一様 でなく, 局所的に大きく変化することが分かる. このような流れの局所的な相違は, 円柱の伝熱特性に影響を及 ぼすと考えられる. そこで著者らは，まずバンク水平方向の円柱本数を 2 本から 10 本, 垂直方向の円柱段数を 1 段から 5 段まで順次変化させた場合について, バンク内の全ての円柱のヌセルト数 $N u_{d}(=h \cdot d / \lambda)$ を測定してみた. その結果, 水平方向の円柱本数が 8 本以上，垂直方向の段数が 5 段以上であれば，バンクの垂直中心線近くに設 置された円柱のヌセルト数は本数や段数をそれ以上増やしても変化しないことから, その值は本数・段数が十分 多いバンクのそれを表していることが分かった．この結果を踏まえて，前報では水平方向の円柱本数を 10 本, 垂 直方向の段数を 5 段格子状に配列したチューブバンクを主たる対象として, 円柱の直径を 2 種類 $(d=8.4,14.4 \mathrm{~mm})$ 変化させ, 水平, 垂直方向の円柱間隔 $G_{h}, G_{v}$ を $G_{h}=10.6-30.6 \mathrm{~mm}, G_{v}=5.6-30.6 \mathrm{~mm}$ の範囲で系統的に変化させた 場合について, 円柱のヌセルト数を測定してみた.

その結果, バンク最下段に設置した円柱のヌセルト数 $N u_{d}$ は, 垂直方向の円柱間隔 $G_{v}$ に依存して变化し, 間隔 $G_{v}$ が狭くなるほど高くなること, また, その值は水平方向の円柱間隔 $G_{h}$ に依らないことが分かった. これに対 して, バンクの 2 段目以降に設置された円柱のヌセルト数 $N u_{d}$ は, 水平, 垂直方向の円柱間隔 $G_{h}, G_{v}$ の両者に依 存して変化する結果を得た. そこで, これら実験で得られたヌセルト数 $N u_{d}$ を種々の無次元パラメータを用いて 再整理することにより, バンクの伝熱がどのようなパラメータに支配されているか調べてみた. その結果, 垂直 方向の円柱間隔 $G_{v}$ をヌセルト数および修正レイリー数の代表長さにとれば，バンク最下段円柱列のヌセルト数 $N u_{G v}\left(=h_{m} \cdot G_{v} / \lambda\right)$ が修正レイリー数 $R a_{G v}{ }^{*}\left(=g \beta q_{w} G_{v}{ }^{4} / \lambda \alpha v\right)$ と $\left(G_{v} / d\right)^{2}$ との積からなる無次元パラメータ $\left[R a_{G v}{ }^{*}\left(G_{v} / d\right)^{2}\right]$ で 整理できることが分かった. その一例として, 最下段円柱列の中心付近に設置された円柱(No. 5 \& 6)のヌセルト 数 $N u_{G v}$ を, 横軸にパラメータ $\left[R a_{G v}{ }^{*}\left(G_{v} / d\right)^{2}\right]$ をとってプロットした結果を図 4(a)に示す. この図より, 円柱のヌセ ルト数 $N u_{G v}$ は円柱直径 $d$, 水平および垂直方向の円柱間隔 $G_{h}, G_{v}$ の如何に依らず, 図中実線で示す直線のまわり にまとまることが分かる，一方，バンクの 2 段目以降に設置された円柱のヌセルト数 $N u_{d}$ についても, 種々の無 次元整理を試みたところ, 各円柱列中心付近に設置された円柱(No.3-No.8)のヌセルト数 $N u_{G v}$ が, 修正レイリー 数 $R a_{G v}{ }^{*}$ と $\left(G_{h} / d\right)$ および $\left(G_{v} / d\right)$ の積からなるパラメータ $\left[R a_{G v}{ }^{*}\left(G_{v} / d\right)\left(G_{h} / d\right)\right]$ で整理できることが分かった. 図 4(b)は その一例として, 3 段目 $(N=3)$ 円柱列の中心付近に置かれた円柱(No. $5 \& 6)$ の又セルト数 $N u_{G v}$ を, 横軸に $\left[R a_{G v}{ }^{*}\left(G_{v}\right.\right.$ $/ d)\left(G_{h} / d\right)$ ]をとってプロットした結果を示寸. この図より, 円柱のヌセルト数 $N u_{G v}$ は円柱直径 $d$, 水平および垂直 方向の円柱間隔 $G_{h}, G_{v}$ の如何に依らず, 図中に示す直線のまわりにまとまることが分かる. また, バンクの $N=2,4$, 5 段目に設置された円柱のヌセルト数 $N u_{G v}$ についても 3 段目と同様にデータがまとまる結果が得られた.

さて, 本研究ではこれら格子配列チューブバンクの成果を踏まえて, 多数の円柱を千鳥状に配列したチューブ バンクについて，バンク内に生じる自然対流の流動と伝熱特性を実験により調べることにした. このような千鳥 


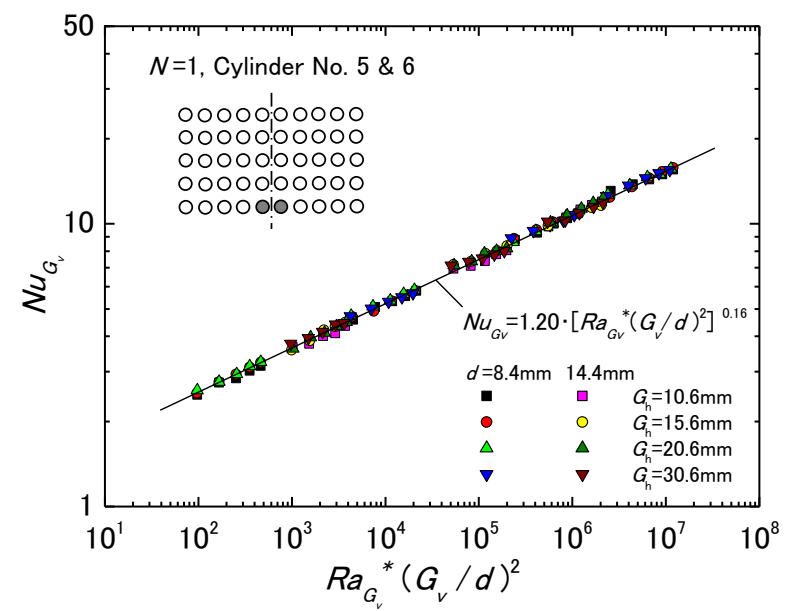

(a) Nusselt numbers for the cylinders No.5 \&6 placed in the bottom row $(N=1)$

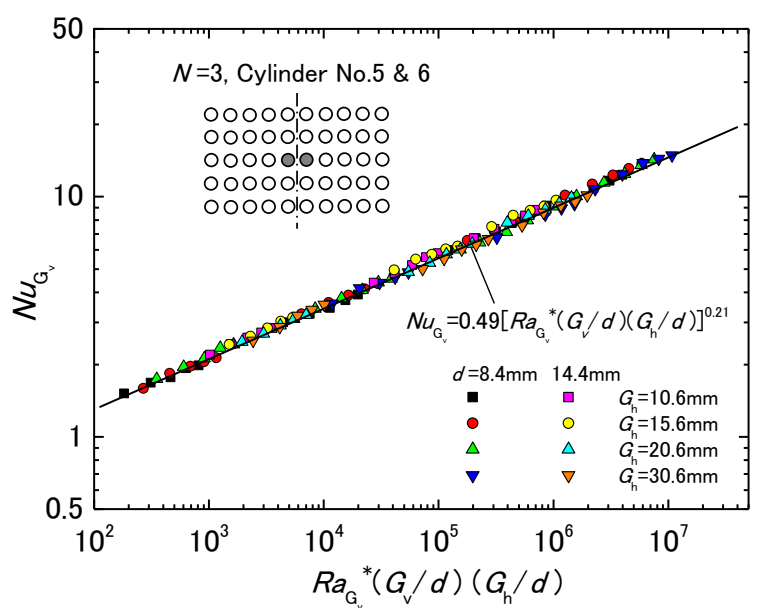

(b) Nusselt numbers for the cylinders No.5\&6 placed in the third row $(N=3)$

Fig. 4 Plots of Nusselt numbers $N u_{G v}$ versus $R a_{G v}{ }^{*}\left(G_{v} / d\right)^{2}$ and $\left[R a_{G v}{ }^{*}\left(G_{v} / d\right)\left(G_{h} / d\right)\right]$ for the cylinders placed near the center of the inline tube banks.

配列バンクは格子配列バンクと並んで，冷暖房用のラジエータやピンフィン型ヒートシンクなどの伝熱機器で見 られる体系であるが，その流動や伝熱特性については現在でも不明のままである，そこで本研究では，まず千鳥 配列バンク内の流動を流れの可視化により把握し, ついでバンクを構成する全ての円柱の熱伝達率を円柱直径, 加熱量, 水平・垂直方向の円柱間隔等を系統的に変化させた場合について測定することにより，これらパラメー タがバンクの伝熱に如何なる影響を及ぼすか調べることにした．さらに，これら熱伝達率を前報の格子配列バン クで得られた無次元パラメータを用いて整理することにより，千鳥配列バンクの伝熱が格子配列バンクと同様な 無次元パラメータで予測可能か否かを調べ，両バンクの伝熱特性の異同を論じることにした.

その具体的な実験であるが，前報の格子配列バンクの結果によれば，水平方向の円柱本数が 8 本以上，垂直方 向の円柱段数が 5 段以上であれば，各水平円柱列の中央付近に設置された円柱のヌセルト数は，本数や段数が十 分多いバンクのそれを表すことを確認している，そこで本研究では，下図 5 に示すように水平方向に 9 本および 10 本の円柱からなる水平円柱列を垂直方向に 5 段千鳥状に配置した体系を主たる実験対象とした。

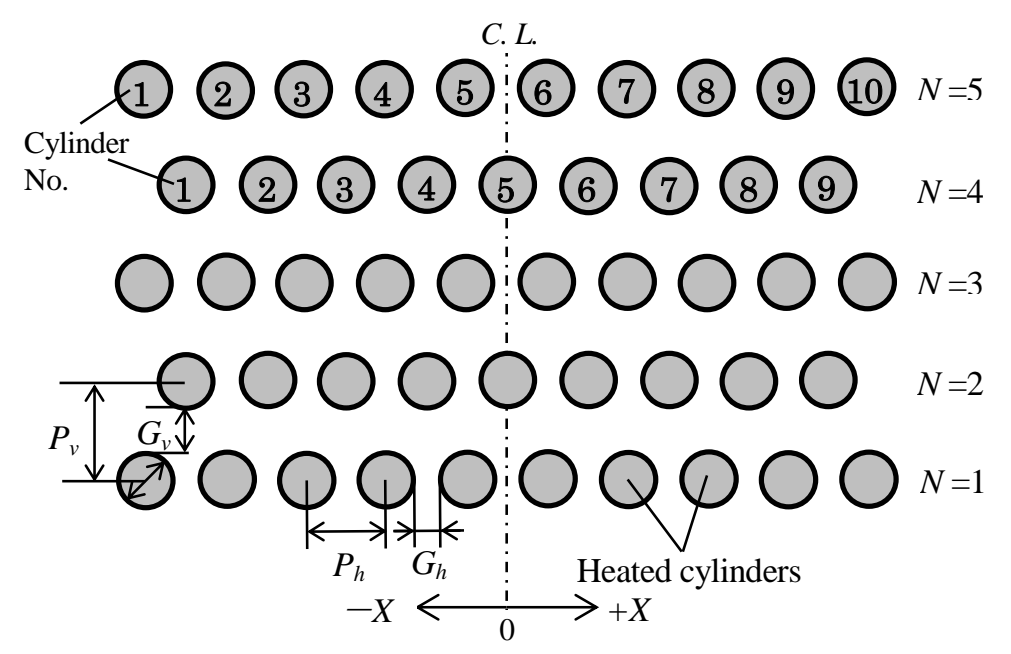

Fig.5 Configuration and notations of present study on staggered tube banks.

\section{2. 実験装置および測定}

本研究では前報 (北村他, 2018) と同様，常温の空気(Pr=0.71)を試験流体とした。また，試験円柱には図 6(a)に示 す市販の円筒状カートリッジヒータを使用した。このヒータは前報で用いたのと同じであり，ニッケル合金製の 発熱線をセラミックスコアに巻き付け，薄肉のステンレスパイプ内に封入したもので，一般には金型加熱用のシ ースヒータとして使用されている，このヒータを採用したのは，本実験のように多数の試験円柱を均しく加熱す 
るには, ヒータの寸法や抵抗值のばらつきが小さいことが必要不可欠なためである. 実験には先の実験と同じく, 直径の異なる 2 種類のカートリッジヒータ(外径 8 および $14 \mathrm{~mm}$ )を使用した. ヒータの長さはいずれも $250 \mathrm{~mm}$ ある. 実験に当たっては，バンクを構成する試験円柱を直列に接続し，直流安定化電源を利用して所定の定電流 を流すことにより, 全ての円柱を等しい熱量 $Q$ で加熱した. この試験円柱の熱伝達率を測定するに当たっては, 円柱表面温度を計測する必要がある.このため線径 $100 \mu \mathrm{m}$ のクロメル・アルメル熱電対を, ヒータの軸方向中心 線上の円筒下端，側面および上端の 3 ケ所にスポット溶接した。このままでは熱電対は円筒外側を流れる空気の 温度を拾うため, 熱電対の外側に厚さ $0.1 \mathrm{~mm}$ の銅䈃をヒータ全周に亘って貼り付けた。このため試験円柱の実外 径 $d$ は $d=8.4$ および $14.4 \mathrm{~mm}$ となった. バンクを構成する全ての円柱にそれぞれ 3 本の熱電対を取り付け, 熱伝 達率を計測することは困難なことから, 水平方向に配置した 9 ないし 10 本の円柱にそれぞれ 3 本の熱電対を取 り付け，この水平円柱列をバンクの垂直方向に一段ずつ移動させていくことにより，バンク内の全円柱の熱伝達 率を測定した. これらの試験円柱を所定の水平および垂直方向間隔 $G_{h}, G_{v}$ で設置するために, 図 6(c)に示す架台 を作成・利用した.この架台の両側板には上述の試験円柱よりも少し大きな $\phi 9$ および $\phi 15 \mathrm{~mm}$ の穴が所定の水平 および垂直方向ピッチ $P_{b}, P_{v}$ で開けられており，この穴に試験円柱を挿入することにより，円柱を水平に保持し た.なお, 本実験では, 直径 $d=8.4$ および $14.4 \mathrm{~mm}$ の円柱とも水平および垂直方向の円柱間隔 $G_{h}, G_{v}$ が $G_{h}=10.6,20.6$, $30.6 \mathrm{~mm}, G_{v}=5.6,10.6,20.6,30.6 \mathrm{~mm}$ となるよう設定した． 伝熱実験は，直径 $d$ の異なる 2 種類の円柱について，間 隔 $G_{v}, G_{h}$ を上の值で瓦いに独立に変化させた合計 24 通りについて行った. この測定に当たり, 各円柱の平均熱伝 達率 $h_{m}$ を次式で定義した。

$$
\left.h_{m}=Q_{w} / A\left(\overline{T_{w}}-T_{\infty}\right)\right\rfloor
$$

ここで, $Q_{w}$ : 円柱表面から自然対流により移動する熱量, $A$ : 円柱表面積, $\overline{T_{w}}$ : 円柱表面温度, $T_{\infty}$ : バンク外側 の周囲流体温度である.このうち対流伝熱量 $Q_{w}$ であるが, 空気の自然対流では円柱表面からの放射伝熱量 $Q_{r}$ が 対流伝熱量 $Q_{w}$ に比べて無視できないことから, 円柱のジュール加熱量 $Q_{j}$ から放射伝熱量 $Q_{r}$ を差し引くことに より求めた. この放射伝熱量 $Q_{r}$ の見積りであるが, 本実験では, 円柱温度 $\overline{T_{w, i j}}$ と周囲流体 $T_{\infty}$ との温度差 $\Delta T$ $\left(=\overline{T_{w, i}}-T_{\infty}\right)$ が最大でも $60 \mathrm{~K}$ 以下となるよう円柱のジュール加熱量 $Q_{j}$ の上限を設定している. このとき水平およ び垂直方向に隣接した 2 本の円柱の温度差は最大でも $10 \mathrm{~K}$ 程度であった. そこで, 円柱間の放射伝熱量は無視で きる程度に小さいと考え, 円柱とバンク外側の周囲空間との放射伝熱量のみ考慮することにした．この円柱と周 囲空間との放射伝熱量 $Q_{r}$ であるが，次式により算出した.

$$
Q_{r, i j}=\sigma \varepsilon\left({\overline{T_{w, i j}}}^{4}-T_{\infty}{ }^{4}\right) \cdot A \cdot F_{i j, \infty}
$$

ここで，上式ののはステファン・ボルツマン定数 $\left(=5.67 \times 10^{-8} \mathrm{~W} / \mathrm{K}^{4}\right), \varepsilon$ は円柱表面の放射率， $F_{i j, \infty}$ は各円柱 $(i, j)$ か ら見たバンク外側空間の形態係数(View factor)である.このうち円柱の放射率 $\varepsilon$ には前報(北村他, 2018) と同じ值 $\varepsilon=0.13$ を採用した. また形態係数であるが, バンクを構成する円柱は同径, 平行かつ無限に長いと仮定すると, 任意の 2 円柱 1,2 間の形態係数 $F_{1-2}$ は次式で求められる.

$$
F_{1-2}=\frac{1}{\pi}\left(\sin ^{-1} \frac{d}{P}+\sqrt{(P / d)^{2}-1}-(P / d)\right)
$$

ここで， $P$ は円柱中心間距離， $d$ は円柱直径. この式(3)を用いて，まずチューブバンク内の任意の円柱 $(i, j) と$, この円柱に隣接寸る複数の円柱 $(i \pm 2, j \pm 2)$ 間の形態係数 $F_{i j-i \pm 2, j \pm 2}$ を計算し, その総和 $\Gamma_{i j}$ を求め, 1 からこの $\Gamma_{i j}$ を差し引くことにより円柱 $(i, j)$ と周囲空間との形態係数 $F_{i j, \infty}$ を求めた. なお， この形態係数 $F_{i j, \infty}$ の值であるが, 本実験範囲内で $F_{i j, \infty}=0.01-0.899$ となり，その值は円柱間隔が狭いバンク中央部の円柱で極小，間隔が広いバン ク最外側 4 隅の円柱で極大となる．なお，これら形態係数 $F_{i j, \infty}$ および計測された各円柱の温度 $\overline{T_{w, i j}}$ を式(2)に代入 し, 放射伝熱量 $Q_{r}$ を計算した結果によれば，本実験の最大温度差 $\Delta T=60 \mathrm{~K}$ の場合でも，バンク中央部に設置さ れた円柱ではジュール加熱量の 2-3\%以下，バンク外側 4 隅の円柱で最大でも $10 \%$ 以下の值となった. つぎに円 柱の表面温度 $T_{w}$ であるが, 上述したように, 本研究では円柱の上下端および側面の3か所で温度を計測している. 
しかし, 計測された 3 地点の温度はほぼ等しく, そのばらつきは本実験の最大温度差 $\Delta T=60 \mathrm{~K}$ の場合でも $\pm 0.5 \mathrm{~K}$ 以内に収まった。これは発熱線からステンレスシース管へ熱が移動する過程で温度が均一化されること，および 空気の熱容量が試験円柱の熱容量に比べて相対的に小さいことが理由として考えられる．このため，それぞれの 円柱はほぼ等温で加熱されているとみなせる. また, 周囲流体温度 $T_{\infty}$ は壁温測定用と同一線径・素材の熱電対 を, バンク最下端円柱列と同一高さでバンク左右端から外側へ $50 \mathrm{~mm}$ 離れた地点に設置・計測した. 円柱は床面 の影響を受けないよう, 架台底面から最小でも $200 \mathrm{~mm}$ 以上離れた位置に設置した. これら試験円柱を装着した 架台を, 断面 $1200 \times 1200 \mathrm{~mm}^{2}$, 高さ $1200 \mathrm{~mm}$ の測定用小部屋の底面中央部に設置した. この測定用小部屋の床面 および天井はステンレス製のパンチングメタル板で製作されており，小部屋の床面から乱れの小さな新気を導入 し，バンクから立ち上る高温のプルームを天井からスムースに排出できるようにしている.

なお，後述する流れの可視化に当たっては，新たに図 6(b)に示す円筒を 10 本製作し, バンクの最下段に設置し た. この円筒は外径 $14 \mathrm{~mm}$ のアクリルパイプの外表面に, 厚さ $20 \mu \mathrm{m}$ のステンレス䇴を幅 $20 \mathrm{~mm}$, 長さ $245 \mathrm{~mm}$ で 2 枚切り, 両面テープで接着したもので, 箔に所定の電流を流すことにより円筒表面を図 6(a)の試験円柱と等し い熱流束で加熱できるようになっている. この円筒中央の箔間隙には, $\phi 1.5 \mathrm{~mm}$ の穴が 2 ケ所開けられており, 円筒内側から線香の煙を円柱表面に向かって静かに吐出させた．この煙を吐出するに当たっては，小型のエアポ ンプを使用し，流れを乱さないよう電圧調整器を用いてポンプの流量を可能な限り低く抑えた。

これらの試験円柱および装置により実現される円柱直径基準の修正レイリー数 $R a_{d}^{*}\left(=g \beta q_{w} d^{4} / \lambda \alpha v\right)$ は $800-$ $3 \times 10^{4}$, 円柱の水平および垂直方向間隔 $G_{h}, G_{v}$ と直径 $d$ との比 $\left(G_{h} / d\right),\left(G_{v} / d\right)$ は, $\left(G_{h} / d\right)=0.736-3.64,\left(G_{v} / d\right)=0.389$ -3.64である. なお, 後述する各種無次元数中の物性值であるが, 体膨張率 $\beta$ は $\beta=1 / T_{\infty}$ で, それ以外の物性值に ついては, 膜温度 $T_{f}=\left(T_{w}+T_{\infty}\right) / 2$ で評価した.

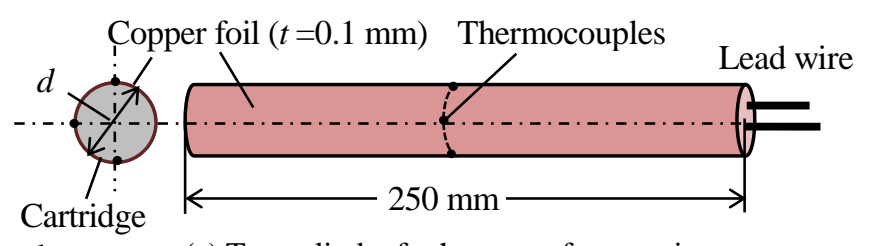

heater

(a) Test cylinder for heat transfer experiment

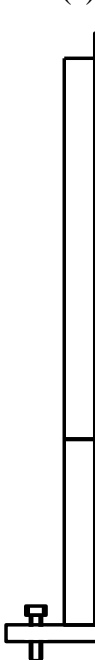

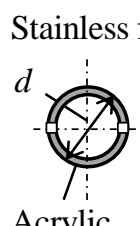

Acrylic

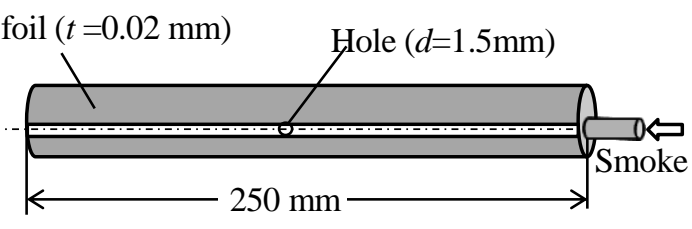

(b) Cylinder for visualization experiment

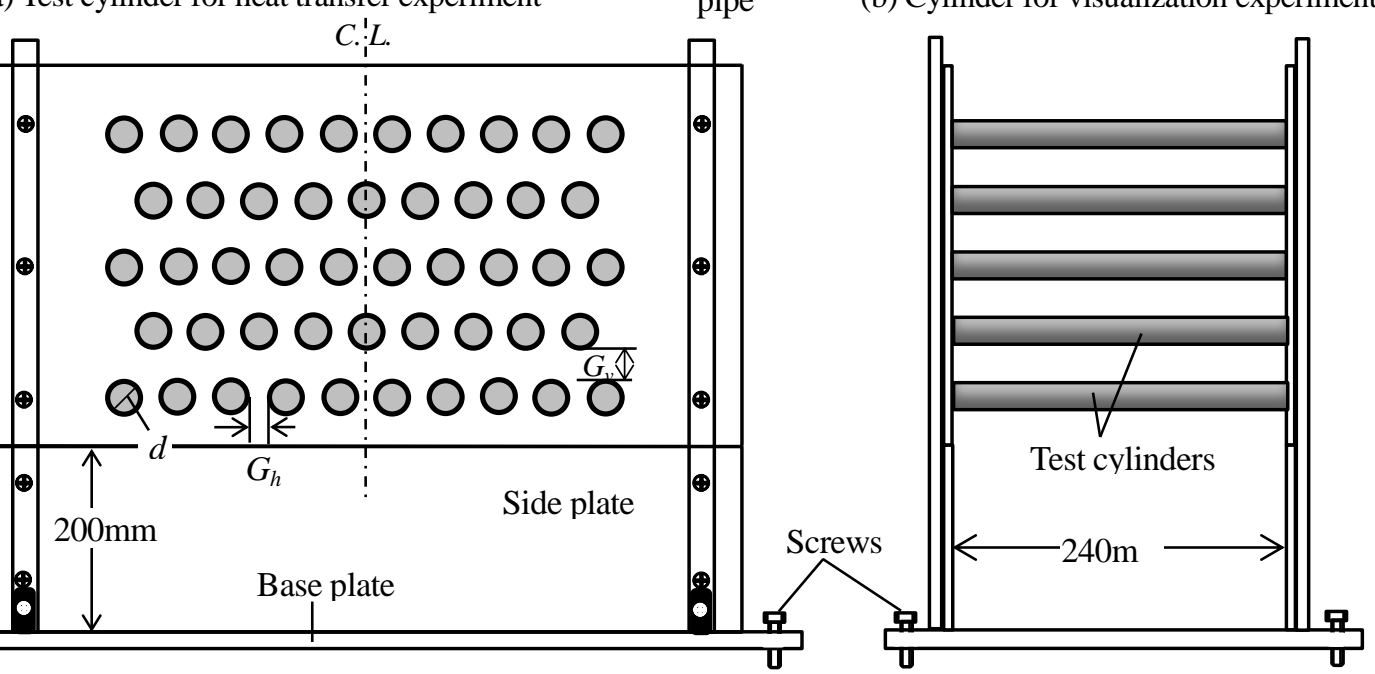

(c) Equipment for fixing test cylinders

Fig.6 Experimental apparatus.

\section{3. 実験結果および考察}

\section{$3 \cdot 1$ 千鳥配列バンク内の流動と円柱のヌセルト数}

本研究では，まず千鳥配列バンク内に生じる自然対流を煙により可視化してみた，その代表的な例として，図 $7(\mathrm{a})$ に直径 $d=14.4 \mathrm{~mm}$ の円柱を水平方向に等間隔 $G_{h}=10.6 \mathrm{~mm}$ で一列に設置し，この水平円柱列を垂直方向に等間 隔 $G_{v}=10.6 \mathrm{~mm}$ で 5 段格子状に設置した場合について, バンク内の流れを可視化した結果を示寸. この図を見てま 
ず気づくのは，バンク最下段に設置された可視化用円柱列のうちとくに外側に設置された円柱から吐出された煙 が鉛直方向でなく，バンク中央に向かって斜めに立ち上がり，全体としてバンクの鉛直中心線上に寄り集まる現 象である.これは本体系のように，多数の熱源（円柱群）が一定の空間を隔てて設置された場合，円柱群内に流 入した空気が円柱によって加熱・加速され，その圧力が円柱群周囲の圧力よりも低くなるために生じるものであ る.このような現象は, 例えばキャンプファイア時に炎や煙がファイアの中心に寄り集まるなど, 我々の身近で ごく普通に観察されるものであるが，従来の研究では，ほとんど考慮されなかった現象である.

そこで本研究では，このようなバンク内の流れがバンク内に設置された円柱の伝熱にどのような影響を及ぼす か調べるために, 可視化と同じ条件でバンク内円柱のヌセルト数 $N u_{d}\left(=h_{m} \cdot d / \lambda\right)$ 学測定してみた. その結果を図 7(b) に示す. なお, この図の横軸にはバンクの水平方向中心線から各円柱中心までの距離 $X(\mathrm{~mm})$ を, 水平方向の円柱 中心間ピッチ $P_{h}\left(=G_{h}+d=25 \mathrm{~mm}\right)$ で規格化した值 $\left(X / P_{h}\right)$ をとっており, 本バンクの下から $1,3,5$ 段目に設置した 10 本円柱列中の各円柱の位置は, 列の外側から中心に向かって順に $\left(X / P_{h}\right)= \pm 4.5, \pm 3.5, \pm 2.5, \pm 1.5, \pm 0.5$ で, また 2,4 段目に設置された 9 本円柱列では $\left(X / P_{h}\right)= \pm 4, \pm 3, \pm 2, \pm 1,0$ で表せ，各位置に設置された円柱のヌセルト数 $N u_{d}$ を図の縦軸にプロットした，なお，図中に記す $N$ は水平円柱列の垂直方向の位置（段数）を表し， $N=1$ は最下段 円柱列， $N=5$ は 5 段目円柱列を示している. また，比較のため， 10 本の円柱を本実験と同じ水平方向円柱間隔 $G_{h}=10.6 \mathrm{~mm}$ で配置した水平単段円柱列のヌセルト数を図に記した. さて, 図 7(b)の結果をみると, バンク内各水 平円柱列のヌセルト数は列中心に対して左右対称な分布を示すこと, その值は最下段円柱列 $(N=1)$ で最も高く, 上 段（下流）側円柱列に行くに従って単調に低下していくことが分かる.このようにヌセルト数が下流に向かって 低下寸るのは，図 7(a)の可視化結果に示したように，下段（上流）側円柱列で加熱され，高温となった空気が上 段（下流）側円柱列の周囲に流れ込むためと考えられる，つぎに各段のヌセルト数変化であるが，最下段円柱列 では, ヌセルト数は列中心付近の円柱で最も高く, 列の外側にいくほど低くなり, 全体として上に凸の分布を示 している. とくに, その值は単段円柱列のヌセルト数よりも全般的に高くなる結果が注目される. 一方, 2 段目 以降の円柱列では, ヌセルト数は円柱列中心付近で高く, 列の外側に向かって低下し, 極小值をとった後, さら に外側の円柱では高い值を示している．このように最外側円柱で高い值となるのは，バンクの外側から低温の周 囲流体が流れ込むためと考えられる。

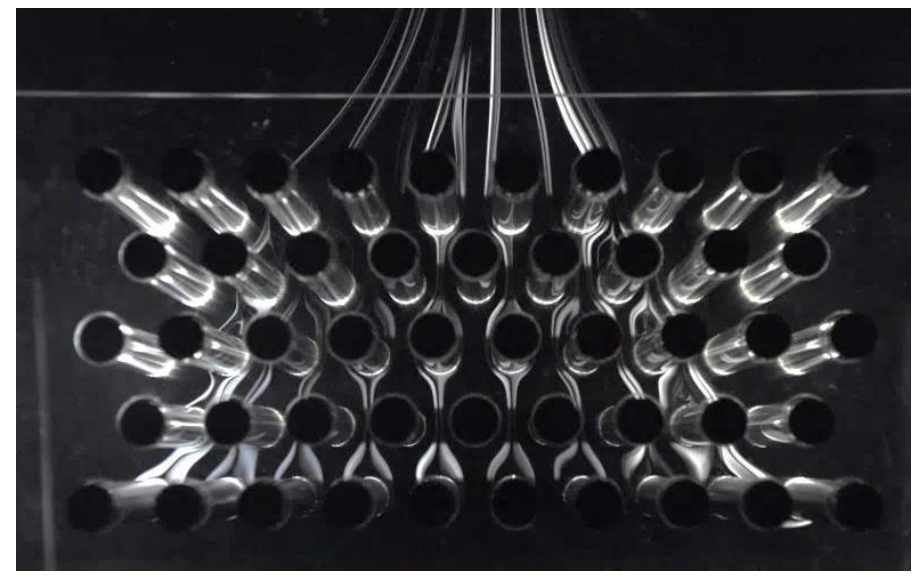

(a) Visualized flow field

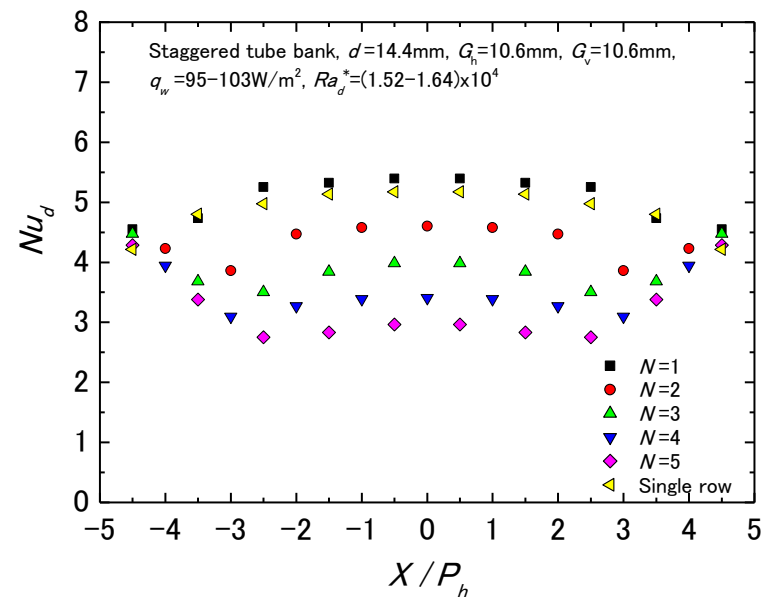

(b) Nusselt numbers of cylinders $N u_{d}$

Fig.7 Visualized flow field and the Nusselt numbers for the staggered tube bank of $d=14.4 \mathrm{~mm}, G_{h}=10.6 \mathrm{~mm}, G_{v}=10.6 \mathrm{~mm}, q_{w}=$ $95-103 \mathrm{~W} / \mathrm{m}^{2}, R a_{d}{ }^{*}=(1.52-1.64) \times 10^{4}$. Figure (a) shows that the smokes arising in the bank gradually gather toward the vertical center-line of the bank. Figure (b) depicts that the Nusselt numbers for the downstream cylinders decrease monotonously, and a marked reduction in the Nusselt numbers is obvious, in particular, for the central cylinders in the row.

本研究では，つぎに上述した千鳥配列バンクの流れと伝熱が，垂直方向の円柱間隔 $G_{v}$ によてどのように変化 するか調べてみた. その一例として, 円柱の水平方向間隔を一定 $G_{h}=10.6 \mathrm{~mm}$ に保ち, 垂直方向間隔 $G_{v}$ を 5.6, 20.6, $30.6 \mathrm{~mm}$ の 3 通り変化させた場合について，バンク内の流れを可視化した結果，および可視化と同じ条件下でバ ンク内各水平円柱列のヌセルト数 $N u_{d}$ を測定した結果を図 8 に示す. まず図 8 左側の可視化結果であるが, 垂直 方向間隔 $G_{v}$ の異なるいずれのバンクでも, バンク下方から流出した煙はバンク中心に向かって寄り集まることが 分かる. しかし, 煙の流跡を最上段円柱列 $(N=5)$ の位置で比較すると, 円柱間隔 $G_{v}$ の増加につれて煙が列中心付 
近のより狭い領域に集中して流れている様子が読み取れる. また，とくにバンク中央付近の流れに注目すると， 最下段円柱から離脱・上昇した煙は，いずれの円柱間隔 $G_{v}$ でも 2 段目円柱列の間を通過し， 3 段目円柱に衝突し た後，4段目円柱の間をすり抜け，5段目円柱へ衝突している様子が観察される.なお，煙の動きを目視観察した ところ, 円柱間隔 $G_{v}$ が広がるにつれて，バンク内で煙が水平方向に大きく搖動することを確認した.

一方，これら可視化と同じ条件下でバンク内各円柱のヌセルト数 $N u_{d}$ を測定した結果をそれぞれ図 8 右側に示 す. なお，図には比較のため，水平方向の円柱間隔 $G_{h}$ が同じ $G_{h}=10.6 \mathrm{~mm}$ の水平単段円柱列のヌセル下数 $N u_{d}$ を 記している. これらの図より, バンク内に設置された各水平円柱列のヌセルト数はいずれの間隔 $G_{v}$ でも, 最下段
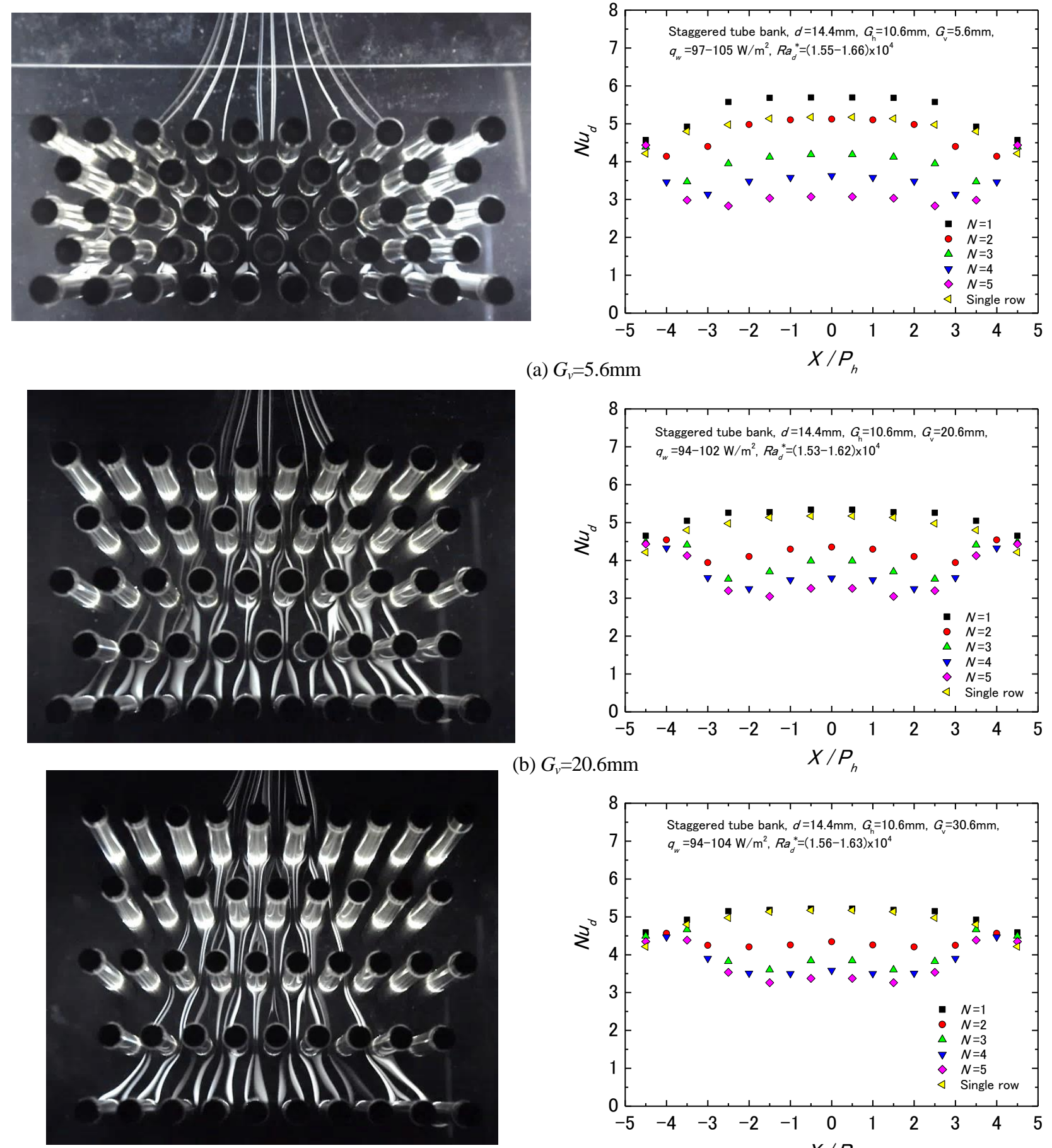

(b) $G_{v}=20.6 \mathrm{~mm}$

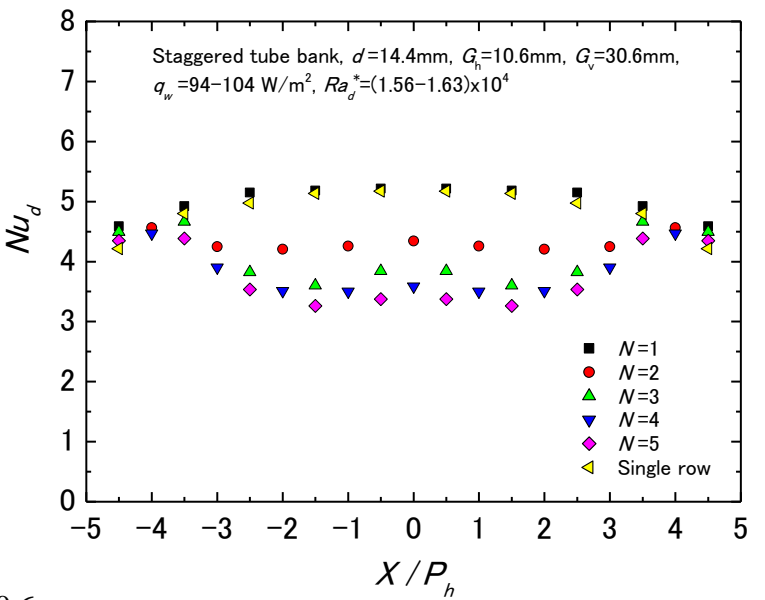

(c) $G_{v}=30.6 \mathrm{~mm}$

Fig. 8 Visualized flow fields and Nusselt numbers for the banks of cylinders, $d=14.4 \mathrm{~mm}, G_{h}=10.6 \mathrm{~mm}, q_{w}=94-105 \mathrm{~W} / \mathrm{m}^{2}, R a_{d}{ }^{*}=$ $(1.53-1.66) \times 10^{4}$, where vertical gaps $G_{v}$ between cylinders are varied as $G_{v}=10.6,20.6$, and $30.6 \mathrm{~mm}$. The photos show that the smokes arising in the banks consistently gather toward the vertical centerline of the banks. The Nusselt numbers show gradual decrease toward downstream. 
円柱列で最も高い值を示し，下流側円柱列に行くに従って低下していくこと，また，バンク最下段と最上段円柱 列のヌセルト数の差は間隔が狭い $G_{v}=5.6 \mathrm{~mm}$ で最も大きく, 間隔 $G_{v}$ の増加につれて次第に縮小していくことが分 かる．これは間隔が増加するにつれて，上流側円柱列から立ち昇るプルームが円柱間で泠され，下流側円柱列の ヌセルト数の低下が抑えられるためと考えられる．つぎに段ごとのヌセルト数変化であるが，とくに最下段円柱 列のヌセルト数は, 円柱間隔が最も狭い $G_{v}=5.6 \mathrm{~mm}$ では単段水平円柱列よりも明らかに高い值を示すのに対し, 間隔 $G_{v}$ が増加するにつれて単段円柱列のヌセルト数に漸近していく結果が注目される. これは最下段円柱列の下 流側に水平円柱列が近接して設置されると，下流側円柱列まわりに誘起された自然対流によって，上流側円柱列 まわりの流れが加速されるためと考えられる．なお，これと同様な結果は前報の格子配列バンクについても得ら れている. 一方，バンク 2 段目以降に設置された円柱列のヌセルト数であるが，いずれの段でも円柱列の中央部 では上に凸の分布を示し，極小值をとった後，円柱列の外側に向かって増加していく結果が読み取れる．また， ヌセルト数が上に凸の分布となる領域は下流側円柱列にいくほど狭くなることが分かる．これらの結果と図 8 左 側の可視化結果を子細に比較すると, 前者の上に凸の分布を示す領域は, 最下段円柱列から立ち昇るプルームが 流れる領域に，また後者のヌセルト数が列の外側に向かって急激に増加していく領域は，バンクの側方から侵入 した流れが支配的な領域に，それぞれ対応していることが分かる.

\section{$3 \cdot 2$ 千鳥配列バンク内円柱のヌセルト数に及ぼす円柱間隔の影響}

前節では水平方向の円柱間隔を一定 $G_{h}=10.6 \mathrm{~mm}$ に保ち, 垂直方向の円柱間隔を $G_{v}=5.6-30.6 \mathrm{~mm}$ の範囲で变化 させた場合について, 千鳥配列バンク内の流れと伝熱特性の概要を述べた. 本研究では, 直径の異なる 2 種類の 円柱 $(d=8.4,14.4 \mathrm{~mm})$ について, 円柱の水平方向間隔を $G_{h}=10.6-30.6 \mathrm{~mm}$, 垂直方向間隔を $G_{v}=5.6-30.6 \mathrm{~mm}$ の範 囲でそれぞれ独立に変化させた場合について，バンクを構成する全ての円柱のヌセルト数 $N u_{d}$ を測定している. そこで, 本節ではこれら円柱間隔がバンク内各水平円柱列のヌセルト数にどのような影響を及ぼすか調べてみた. 紙面の制約もあり，全ての結果を紹介することは困難なことから，ここでは直径 $d=14.4 \mathrm{~mm}$ の円柱について，水 平方向の円柱間隔を一定 $G_{h}=20.6 \mathrm{~mm}$ に保ち, 垂直方向間隔 $G_{v}$ を変化させた場合, および垂直方向間隔を一定 $G_{v}=10.6 \mathrm{~mm}$ とし, 水平方向円柱間隔 $G_{h}$ を変化させた $2 つ の$ 場合について, バンク最下段 $(N=1), 2$ 段目 $(N=3)$ およ び 5 段目 $(N=5)$ に設置された水平円柱列のヌセルト数 $N u_{d}$ を測定した結果を示すことにする. そのうち最下段円柱 列 $(N=1)$ のヌセルト数 $N u_{d}$ を測定した結果を図 9 に示寸. 図 9(a) は垂直方向間隔 $G_{v}$ を変化させた場合, 図 9(b)は水 平方向間隔 $G_{h}$ を変化させた場合の結果を示したものである. この図 9(a)から最下段円柱列のヌセルト数は, 垂直 方向間隔 $G_{v}$ に依存して変化し, 前節で述べた $G_{h}=10.6 \mathrm{~mm}$ の場合と同様, その值は間隔が狭い $G_{v}=5.6 \mathrm{~mm}$ で最も 高く, $G_{v}$ の増加と共に低下していくことが分かる.このように $G_{v}$ が狭い場合にヌセルト数が高くなるのは，バ ンクの下流側に設置された円柱のまわりに誘起された自然対流により上流側円柱間を通過する流れが加速される ためと考えられる. 一方, 水平方向の円柱間隔を $G_{h}=10.6-30.6 \mathrm{~mm}$ の範囲で変化させた図 9(b)の結果をみると, 最下段円柱列のヌセルト数は $G_{h}$ によらず，ほぼ一定な值を示すことが分かる. なお，このように最下段円柱列の

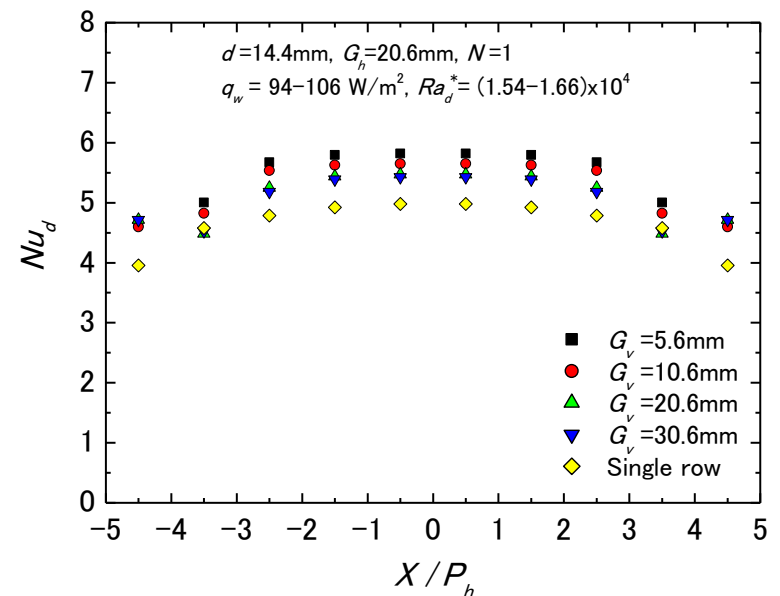

(a) Nusselt numbers for fixed horizontal gap $G_{h}=20.6 \mathrm{~mm}$

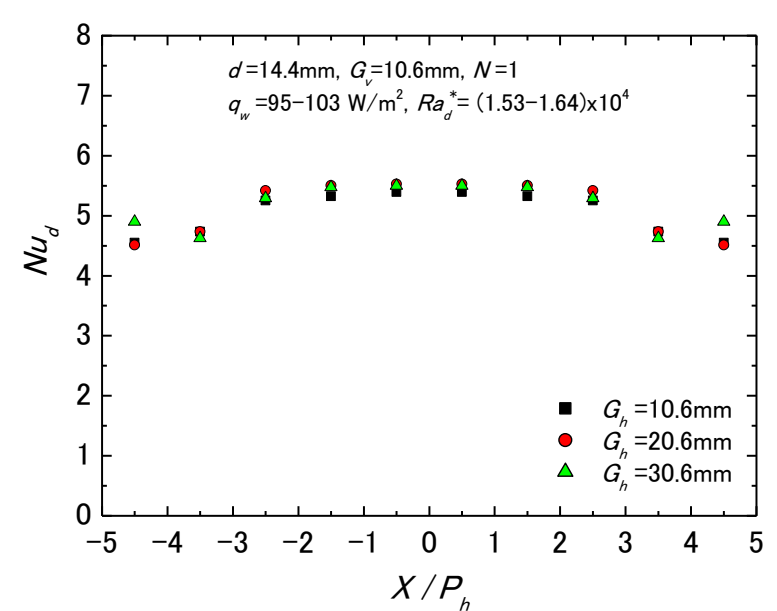

(b) Nusselt numbers for fixed vertical gap $G_{v}=10.6 \mathrm{~mm}$

Fig.9 Nusselt numbers for the first horizontal row $(N=1)$ in the staggered tube bank, where the horizontal gap is fixed as $G_{h}$ $=20.6 \mathrm{~mm}$ in Fig.(a), while the vertical gap is fixed as $G_{v}=10.6 \mathrm{~mm}$ in Fig.(b). One will see from Fig.(a) that the Nusselt numbers decrease with the vertical gap $G_{v}$, while from Fig.(b) the numbers are independent of the horizontal gaps $G_{h}$. 
ヌセルト数が $G_{v}$ のみに依存して変化する結果は, 前報の格子配列バンクでも同様に得られている.

つぎに 2 段目 $(N=2)$ おび 5 段目 $(N=5)$ 円柱列のヌセルト数 $N u_{d}$ を，上と同じ水平および垂直方向間隔 $G_{h}, G_{v}$ の 下で測定した結果を図 10 に示す。まず 2 段目円柱列のヌセルト数であるが，水平方向の円柱間隔を一定 $G_{h}=20.6 \mathrm{~mm}$ とした図 10(a)の結果を見ると，図 9(a)に示した最下段円柱列 $(N=1)$ と同様， ヌセルト数は間隔が狭い $G_{v}=5.6 \mathrm{~mm}$ で最も高く, 間隔 $G_{v}$ の増加と共に低下していくことが分かる. これは 1 段目円柱列と同様，間隔 $G_{v}$ が狭いほど下流側円柱列による誘引効果が強く働き, 円柱列近傍の流れが加速されるためと考えられる. 一方, $G_{v}=10.6 \mathrm{~mm}$ 一定とした図 10(b)の結果をみると, 2 段目円柱列中心付近のヌセルト数は, 水平方向の円柱間隔が広 い $G_{h}=20.6,30.6 \mathrm{~mm}$ ではほぼ等しい值となるのに対して, 間隔が狭い $G_{h}=10.6 \mathrm{~mm}$ では列全体に亘って明らかに低 い值を示すことが分かる。これは 2 段目円柱列の円柱間には最下段円柱列を離脱・上昇して来た高温のプルーム が流れるが，円柱間隔が狭い $G_{h}=10.6 \mathrm{~mm}$ の場合には，この高温プルームにより 2 段目円柱近傍の流体温度が高く なり，ヌセルトが低下するのに対して，間隔が広い $G_{h}=20.6,30.6 \mathrm{~mm}$ の場合には，プルームは円柱から離れた地 点を通過するため, 円柱近傍の流体温度は低く抑えられ, ヌセルト数がほぼ一定の高い值を示すと考えられる.

つぎに 5 段目円柱列のヌセルト数 $N u_{d}$ であるが, $G_{h}=20.6 \mathrm{~mm}$ 一定とした図 $10(\mathrm{c})$ から, 列中央付近の円柱のヌセ ルト数は 2 段目円柱列とは逆に，垂直方向間隔 $G_{v}$ が広くなるにつれて高くなることが分かる. これは間隔 $G_{v}$ が 広くなるにつれて，4 段目円柱列から上昇して来たプルームが円柱間でより冷やされ，円柱のヌセルト数が高く なったと考えられる. 一方， $G_{v}=10.6 \mathrm{~mm}$ 一定とした図 $10(\mathrm{~d})$ では，水平方向間隔 $G_{h}$ が狭くなるにつれてヌセルト 数 $N u_{d}$ が低下していく様子が読み取れる. これは上述した 2 段目円柱列と同様な理由によるものと考えている. また，これらの結果よりバンク 2 段目以降の円柱列では, 水平および垂直方向の円柱間隔 $G_{h}, G_{v}$ に応じてヌセル 卜数が複雑に変化することが分かる.

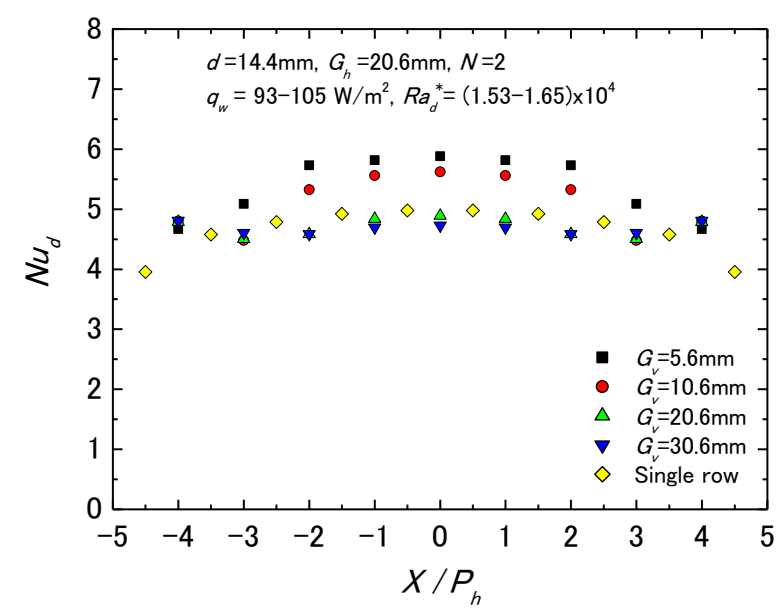

(a) Nusselt numbers of 2nd-row at fixed $G_{h}=20.6 \mathrm{~mm}$

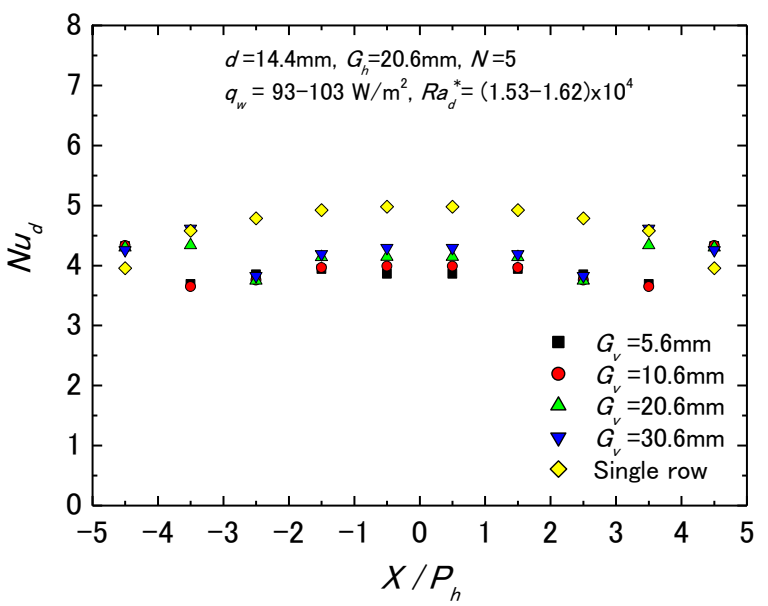

(c) Nusselt numbers of 5th-row at fixed $G_{h}=20.6 \mathrm{~mm}$

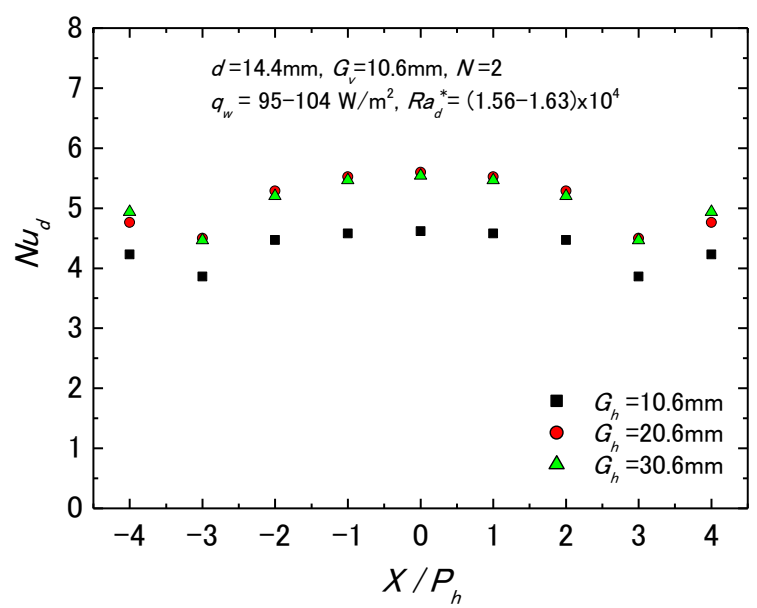

(b) Nusselt numbers of 2nd-row at fixed $G_{v}=10.6 \mathrm{~mm}$

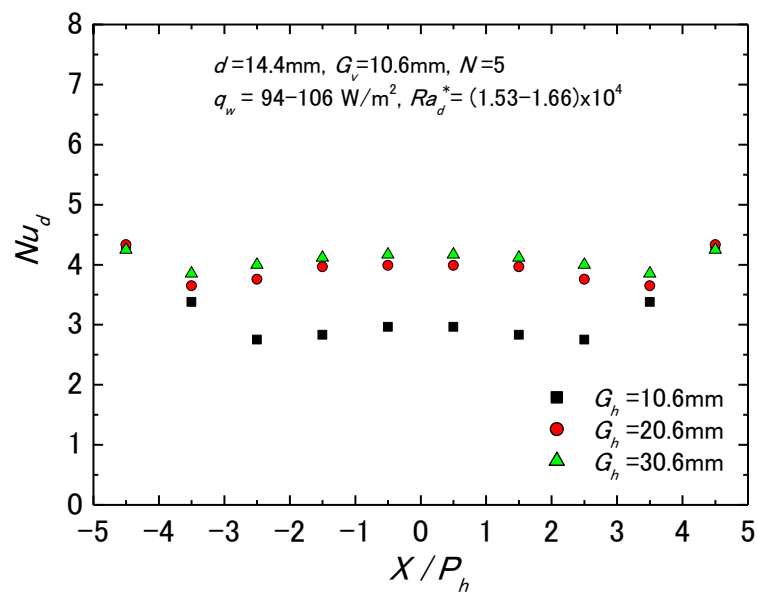

(d) Nusselt numbers of 5th-row at fixed $G_{v}=10.6 \mathrm{~mm}$

Fig.10 The influence of vertical and horizontal gaps $G_{v}, G_{h}$ on the Nusselt numbers for the second and fifth horizontal rows $(N=2 \& 5)$ in the staggered tube banks of $d=14.4 \mathrm{~mm}$. The plots show that the Nusselt numbers depend not only on the vertical gaps but also on the horizontal gaps. Similar results are obtained for the third and fourth rows. 


\section{$3 \cdot 3$ 千鳥および格子配列バンク内の流れとヌセルト数の比較}

本研究では，つぎに前述した千鳥配列バンク内の流れとヌセルト数 $N u_{d}$ を，前報の格子配列バンクのそれと比 較し，両者の異同を論じることにした。このために千鳥配列と同一の条件下で格子配列バンク内の流れを今回新 たに可視化してみた，その一例として水平および垂直方向間隔が $G_{h}=10.6 \mathrm{~mm}, G_{v}=10.6 \mathrm{~mm}$ の格子配列バンクの可 視化結果を図 11(a)に示し，同じ条件下で千鳥配列バンク内の流れを可視化した結果を図 11(b)に示す。さて，図 11(a)の格子配列バンクの可視化結果を見ると，最下段円柱列から吐出された煙は，図 11(b)の千鳥配列と同様，バ ンク中心線に向かって寄り集まる様子が読み取れる.しかし，とくにバンク中央付近の流れを詳しく観察すると，

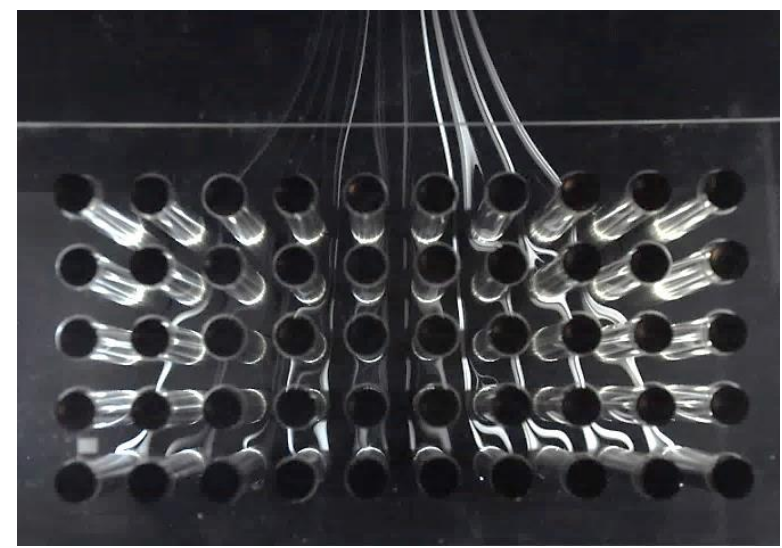

(a) Inline tube bank

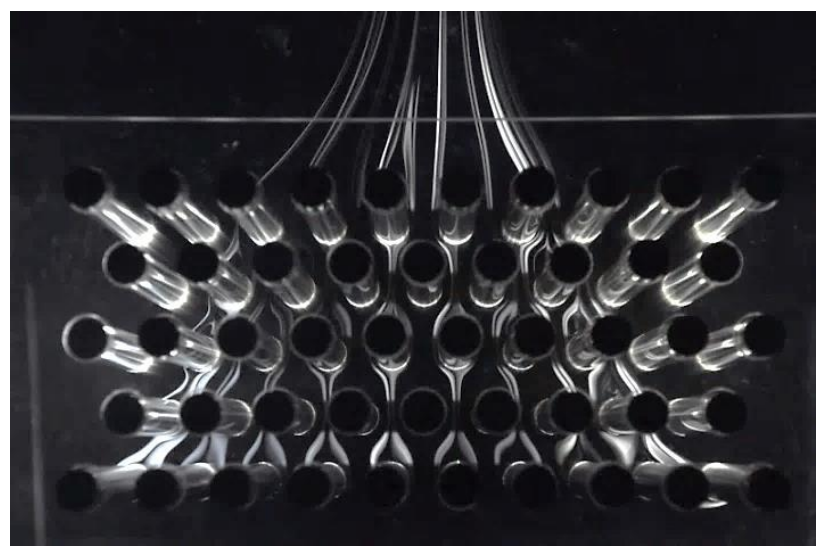

(b) Staggered tube bank

Fig.11 Visualized flow fields in staggered and inline tube banks of $d=14.4 \mathrm{~mm}, G_{h}=10.6 \mathrm{~mm}, G_{v}=10.6 \mathrm{~mm}, q_{w} \simeq 100 \mathrm{~W} / \mathrm{m}^{2}, R a_{d}{ }^{*} \simeq 1.6 \times 10^{4}$.

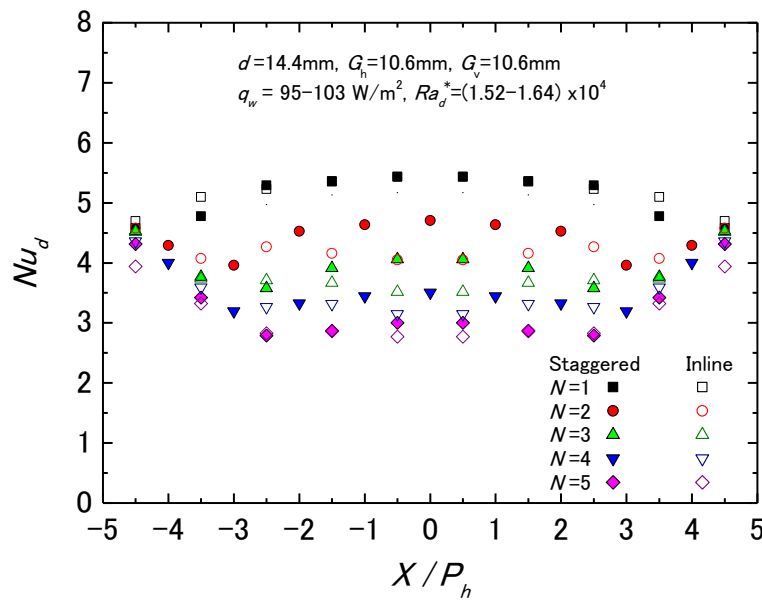

(a) $G_{v}=10.6 \mathrm{~mm}$

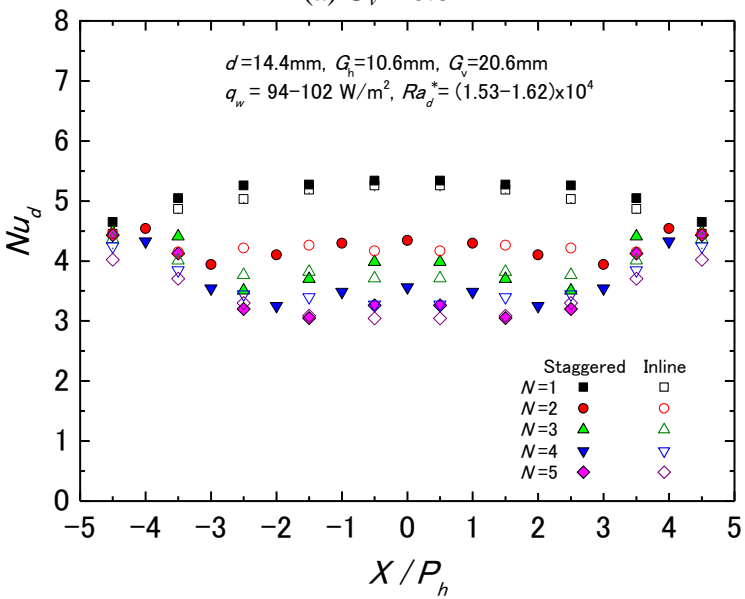

(c) $G_{v}=20.6 \mathrm{~mm}$

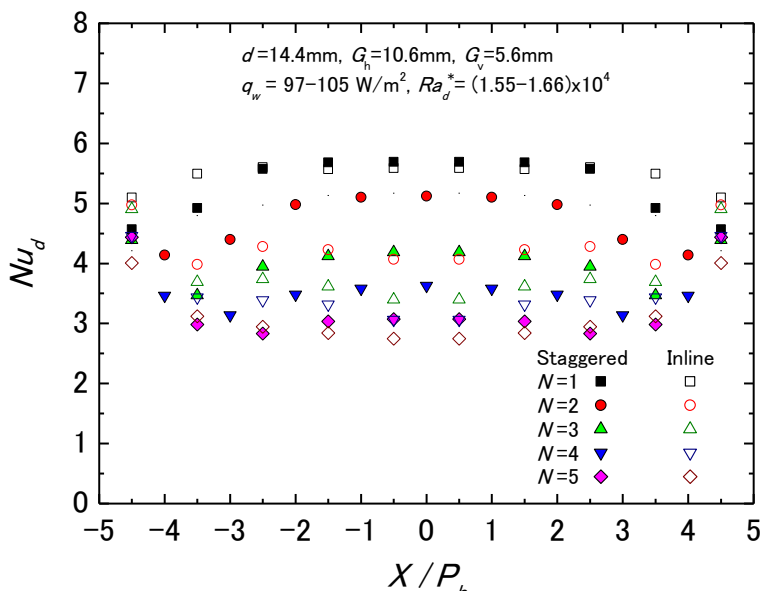

(b) $G_{v}=5.6 \mathrm{~mm}$

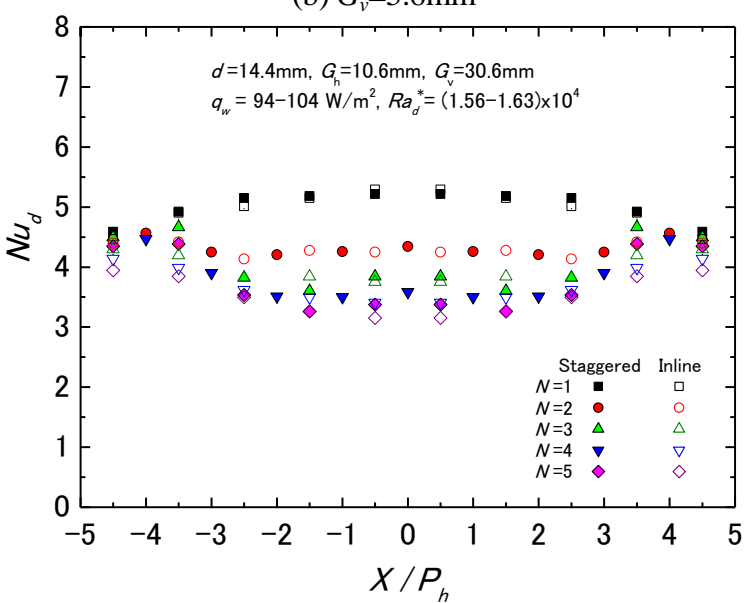

(d) $G_{v}=30.6 \mathrm{~mm}$

Fig.12 Comparison of the Nusselt numbers between staggered and inline tube banks of $d=14.4 \mathrm{~mm}$, where the horizontal gap is fixed at $G_{h}=10.6 \mathrm{~mm}$, while the vertical gap is varied as $G_{v}=10.6,5.6,20.6$ and $30.6 \mathrm{~mm}$. The figures show that Nusselt numbers for the first row $(N=1)$ are almost identical in between staggered and inline banks. While the cylinders placed near the center of the second to fifth rows in the staggered bank show higher Nusselt numbers than those in the inline tube bank. 
図 11 (a)の格子配列では，最下段円柱を離脱した煙は 2 段目円柱に衝突し，2 段目円柱表面に沿って流れた後，再 度離脱・上昇し，3，4，5段目円柱に次々に衝突・離脱を繰り返しながら，バンク上方へと流れ去っていく.これ に対して，千鳥配列の場合には，図 11(b)に示すように最下段円柱を離脱した煙は 2 段目円柱列の間を通過し，3 段目円柱に衝突し，3 段目円柱の表面に沿って流れた後，再び離脱・上昇し，4段目円柱列の間を流れ，5段目円 柱に衝突している．このような流れの相違はバンク中央部に設置された円柱のヌセルト数に影響を及ぼすことが 予想される. そこで, 本報で得た千鳥配列バンクのヌセルト数を前報の格子配列バンクのそれと比較してみた.

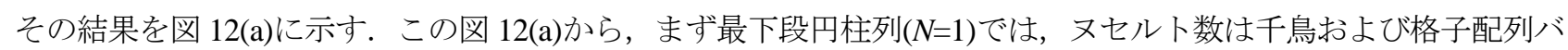
ンクでほぼ等しくなることが分かる. 一方， 2 段目 $(N=2)$ 円柱列では, 列中央付近で千鳥配列の方が格子配列に 比べてヌセルト数が高くなることが分かる.これは図 11 に示したように, 格子配列では最下段円柱列から立ち昇 る高温の自然対流プルームが 2 段目円柱に直接衝突するのに対して，千鳥配列ではプルームが円柱間を通過する ため， 円柱近傍の流体温度が低く抑えられるためと考えられる．また， 3, 4, 5 段目円柱列についても 2 段目円柱 列と同様, 千鳥配列の方が高い又セルト数が得られている. しかし, 両者の差は下流側円柱列にいくに従って次 第に小さくなり，ヌセルト数が高くなる領域も円柱列中心近傍に限られることが分かる.

本研究では，つぎにこれら千鳥および格子配列バンクのヌセルト数 $N u_{d}$ に対して，水平および垂直方向の円柱 間隔 $G_{h}, G_{v}$ がどのような影響を及ぼすか調べてみた. その結果の一例として, 水平方向間隔を一定 $G_{h}=10.6 \mathrm{~mm}$ と し, 垂直方向間隔を $G_{v}=5.6,20.6,30.6 \mathrm{~mm}$ の 3 通り変化させた場合について, ヌセルト数を比較した結果を図 12 (b), (c), (d)に示す．まず，これらの図の最下段円柱列 $(N=1)$ のヤルト数であるが，間隔 $G_{v}$ が異なるいずれの図で も, 千鳥と格子配列でヌセルト数がほぼ等しい值となることが分かる. つぎに 2 段目円柱列 $(N=2)$ のマセルト数で あるが，図 12(b)に示寸ように垂直方向の円柱間隔が最も狭い $G_{v}=5.6 \mathrm{~mm}$ では，とくに列中心付近で千鳥配列の方 が格子配列に比べてヌセルト数が顕著に高くなることが分かる. 一方，その差は間隔 $G_{v}$ が $10.6 \mathrm{~mm}$ (図 12(a)), 20.6mm（図 12(c)），30.6mm（図 12(d)）と増加するにつれて次第に小さくなっていく様子が読み取れる. これと 同様な結果は 3 段目 $(N=3), 4$ 段目 $(N=4)$ およ゙ 5 段目 $(N=5)$ 円柱列中心付近のヌセルト数についても言え，とくに 間隔が最も広い $G_{v}=30.6 \mathrm{~mm}$ では，図 $12(\mathrm{~d})$ に示寸ように千鳥配列と格子配列で差が認められなくなることが分か る.これは垂直方向の円柱間隔が広がるにつれて上流側円柱列から立ち昇るプルームが左右に搖動し始め, この 搖動によって下流側円柱列まわりの速度および温度場が水平方向に一様化され, 千鳥配列と格子配列で差が生じ なくなるためと考えられる.

\section{$3 \cdot 4$ 千鳥配列バンクのヌセルト数の無次元整理および格子配列バンクとの比較}

さて, 前節では円柱の水平および垂直方向間隔 $G_{h}, G_{v}$ が千鳥配列バンクのヌセルト数 $N u_{d}$ にどのような影響を 及ぼすか論じたが, これらヌセルト数に対しては円柱間隔 $G_{h}, G_{v}$ だけでなく, 円柱の直径 $d$ や加熱量 (熱流束 $q_{w}$ ) が影響を及ぼすと考えられる．これら多くのパラメータに依存して変化するチューブバンクの伝熱特性を定量的 かつ一般的に予測するには，バンク内に設置された各円柱のヌセルト数について無次元整理を試み，バンクの伝 熱を支配する無次元パラメータを明らかにすることが必要と思われる. このことから, 著者らは前報(北村他, 2018) で格子配列バンクのヌセルト数を種々の無次元パラメータを用いて整理してみた，その結果，本論文の緒 言に述べたように, 垂直方向の円柱間隔 $G_{v}$ をヌセルト数および修正レイリー数の代表長さにとれば, バンク最下 段円柱列のヌセルト数 $N u_{G v}\left(=h_{m} \cdot G_{v} / \lambda\right)$ が修正レイリー数 $R a_{G v}{ }^{*}\left(=g \beta q_{w} G_{v}{ }^{4} / \lambda \alpha v\right)$ と $\left(G_{v} / d\right)^{2}$ との積からなる無次元パ ラメータ $\left[R a_{G v}{ }^{*}\left(G_{v} / d\right)^{2}\right]$ で整理できること, またバンクの 2 段目以降に設置された水平円柱列の中央付近に設置さ れた円柱のヌセルト数 $N u_{G v}$ が, 修正レイリー数 $R a_{G v}{ }^{*}$ と $\left(G_{h} / d\right)$ および $\left(G_{v} / d\right)$ の積からなるパラメータ $\left[R a_{G v}{ }^{*}\left(G_{v} / d\right)\left(G_{h}\right.\right.$ /d)]で整理できることを明らかにした。

そこで本研究では，これら前報の結果を踏まえ，千鳥配列バンクのヌセルト数が格子配列バンクと同じ無次元 パラメータにより整理可能か否か調心゙ることにした. そのうち図 13 は, 最下段円柱列 $(N=1)$ について実験值を整 理した結果を示したもので, 図の縦軸には垂直方向間隔 $G_{v}$ 基準のヌセルト数 $N u_{G v}$ をとり, 横軸にパラメータ $R a_{G v}{ }^{*}\left(G_{v} / d\right)^{2}$ をとっている. 図13(a)は円柱列中心付近 $\left(X / P_{h}\right)= \pm 0.5$ に設置された円柱 (No.5 \& 6)のヌセルト数 $N u_{G v}$ を, また図 13(b)は, 円柱列中心から $\left(X / P_{h}\right)= \pm 2.5$ 離れた円柱(No.3 \&8)のヌセルト数 $N u_{G v}$ を整理した結果を示し たものである. なお，この整理に当たっては，前報と同じくバンク中心線に対して対称な位置に設置された 2 本 の円柱のヌセルト数を算術平均した值を用いている. この図13(a),(b)から, それぞれの円柱のヌセルト数 $N u_{G v}$ は 
パラメータ $R a_{G v}{ }^{*}\left(G_{v} / d\right)^{2}$ に対して直線的に変化し, 両図中に示す直線のまわりにまとまることが分かる.ここで, 図中の直線は千鳥配列と同じ位置に設置された格子配列の円柱のヌセルト数 $N u_{G v}$ をパラメータ $R a_{G v}{ }^{*}\left(G_{v} / d\right)^{2}$ を用 いて整理した前報の結果を示したものである.この結果より，千鳥配列バンクの最下段に設置された No.5\&6 お よびNo.3\&8 円柱のヌセルト数 $N u_{G v}$ は, 格子配列バンクのヌセルト数に一致することが分かる. なお, 図中に記 した直線の式は両者の関係を次式(4)で近似し,

$$
N u_{G v}=C_{1} \cdot\left[R a_{G v}{ }^{*}\left(G_{v} / d\right)^{2}\right]^{m}
$$

実験值に最も良く合う係数 $C_{1}$ および指数 $m$ を求めたもので, 円柱 No.5 \& 6 に対しては $C_{1}=1.20, m=0.18$, 円柱 No.3 $\& 8$ に対しては $C_{1}=1.10, m=0.18$ なる值を得ている. なお，本実験では最下段円柱列の他の円柱についても上と同 様な無次元整理を試み, そのヌセルト数 $N u_{G v}$ がパラメータ $\left[R a_{G v}{ }^{*}\left(G_{v} / d\right)^{2}\right]$ で整理できることを確認している.

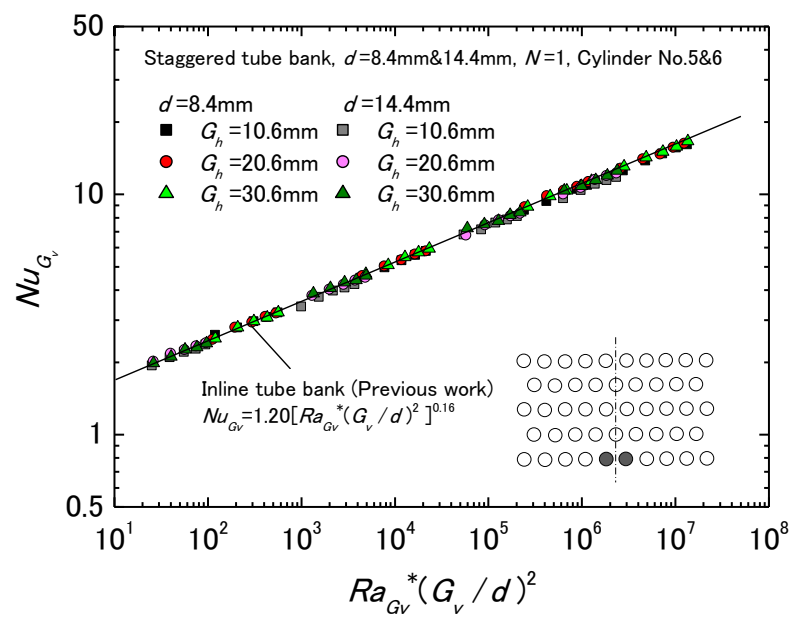

(a) Cylinders No.5 and No.6

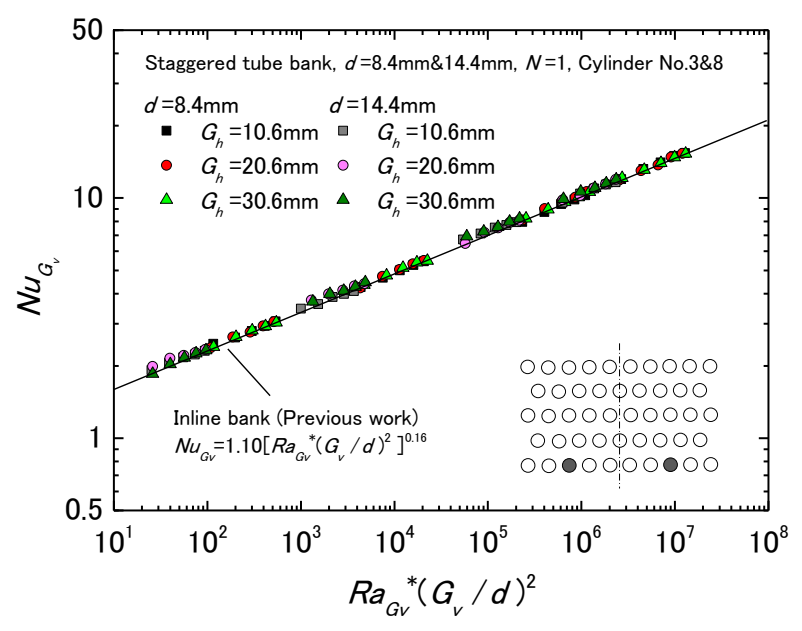

(b) Cylinders No.3 and No.8

Fig.13 Rearrangements of Nusselt numbers for the cylinders of No.5\&6 and No.3\&8 in the first horizontal row $(N=1)$, where Nusselt numbers $N u_{G v}$ based on the vertical gaps $G_{v}$ are plotted with the parameter $\left[R a_{G v}{ }^{*}\left(G_{v} / d\right)^{2}\right]$. The plots gather around the solid lines in the figures, indicating that the parameter $\left[R a_{G v}{ }^{*}\left(G_{v} / d\right)^{2}\right]$ well correlates the Nusselt numbers $N u_{G v}$. Moreover, the plots coincide fairly well with the previous correlations for the inline tube banks.

つぎに千鳥配列バンクの 2 段目以降に設置された水平円柱列の中心付近に設置された円柱のヌセルト数 $N u_{G v}$ を前報の格子配列バンクと同じパラメータ $\left[R a_{G v}{ }^{*}\left(G_{v} / d\right)\left(G_{h} / d\right)\right]$ で整理した結果を図 14 に示す. 図 14(a), (c)は 2 段目

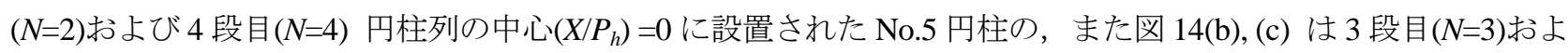
び 5 段目 $(N=5)$ 円柱列の中心付近 $\left(X / P_{h}\right)= \pm 0.5$ に設置された No.5\&6 円柱のヌセルト数 $N u_{G v}$ をそれぞれプロット したものである.これらの図から千鳥配列バンクの中心付近に設置された円柱のヌセルト数 $N u_{G v}$ は, いずれの段 $N=2-5$ においても, パラメータ $\left[R a_{G v}{ }^{*}\left(G_{v} / d\right)\left(G_{h} / d\right)\right]$ 対して直線的に変化し, 図中に記した直線のまわりにまと まることが分かる。そこで，これらの直線を次式(5)で近似し，

$$
N u_{G v}=C_{2} \cdot\left[R a_{G v}{ }^{*}\left(G_{v} / d\right)\left(G_{h} / d\right)\right]^{n}
$$

式中の係数 $C_{2}$ および指数 $n$ を求めたところ, 2 段目円柱列では $C_{2}=0.87, n=0.18,3$ 段目円柱列では $C_{2}=0.66, n=0.195$, 4 段目円柱列では $C_{2}=0.56, n=0.205,5$ 段目円柱列では $C_{2}=0.46, n=0.215$ なる值を得た。 なお，これらの相関式はバ ンク 2-5 段目に設置された円柱(No.5 \& 6)のヌセルト数 $N u_{G v}$ を, それぞれ $\pm 5.5 \%, \pm 6.2 \%, \pm 5.1 \%, \pm 5.3 \%$ 程度の誤 差で予測する. また, 図 $15(\mathrm{a})-(\mathrm{d})$ のプロットあるいは相関式から, 円柱列中心付近の円柱のヌセルト数 $N u_{G v}$ は 下流側円柱列にいくほど低くなり， $\left[R a_{G v}{ }^{*}\left(G_{v} / d\right)\left(G_{h} / d\right)\right]$ に対する勾配が急になることが分かる．なお，比較のため 格子配列バンク中心付近の円柱(No.5\&6)のヌセルト数 $N u_{G v}$ を同じパラメータ $\left[R a_{G v}{ }^{*}\left(G_{v} / d\right)\left(G_{h} / d\right)\right]$ で整理した結果 を図中実線で記した. 図を見ると, いずれの段でも千鳥配列のヌセルト数 $N u_{G v}$ の方が格子配列に比べて高い值を 示すこと, また, その差は $\left[R a_{G v}{ }^{*}\left(G_{v} / d\right)\left(G_{h} / d\right)\right]$ が小さな領域, すなわち円柱間隔 $G_{v}, G_{h}$ が狭い場合に大きく, $\left[R a_{G v}{ }^{*}\left(G_{v}\right.\right.$ 
ld $\left.\left(G_{h} / d\right)\right]$ が増加するにつれて次第に小さくなることが分かる.この結果は，円柱を狭い間隔で配置する場合， 格子状に配列するよりも千鳥状に配列する方がより高い伝熱性能が得られることを意味しており，チューブバン クやピンフィン型ヒートシンク等の伝熱性能向上を図る上で重要な結果と思われる.

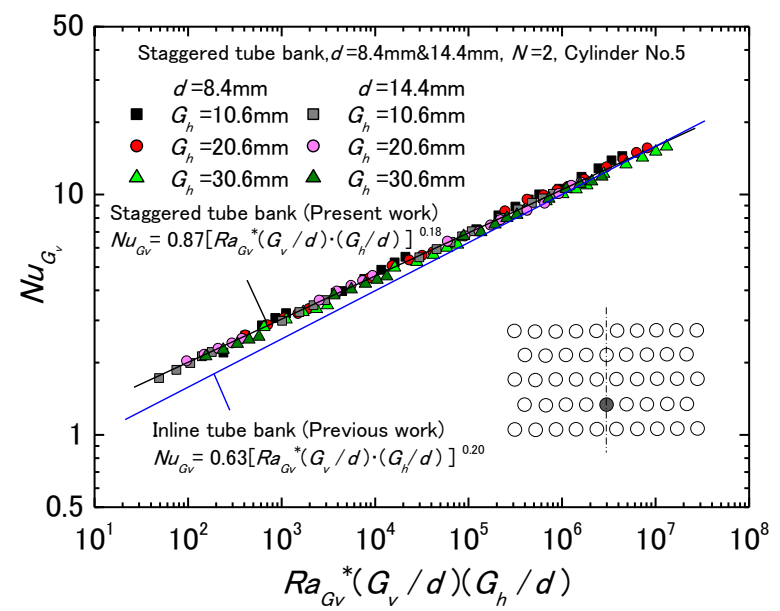

(a) Second- row $(N=2)$

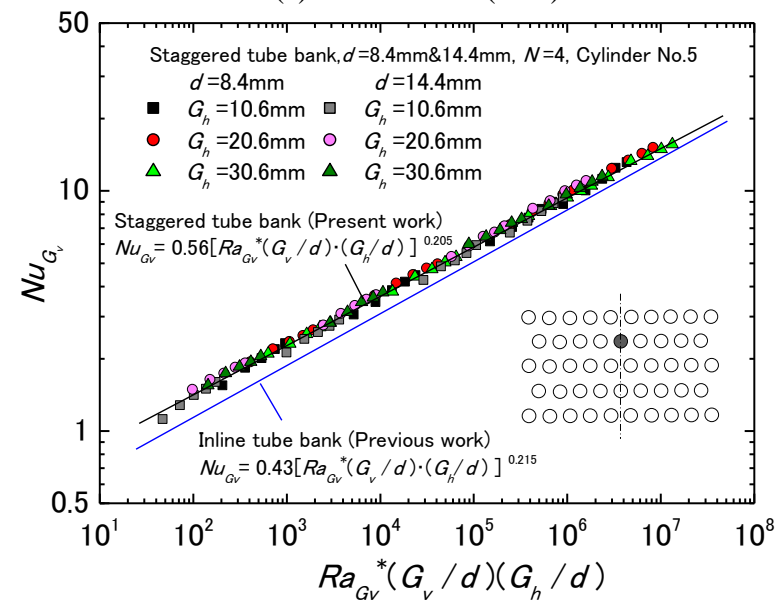

(c) Fourth-row $(N=4)$

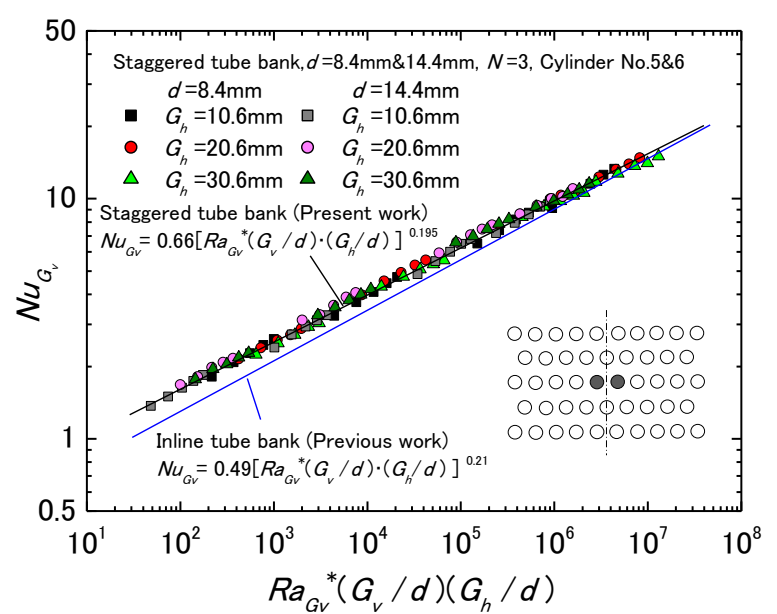

(b) Third- row $(N=3)$

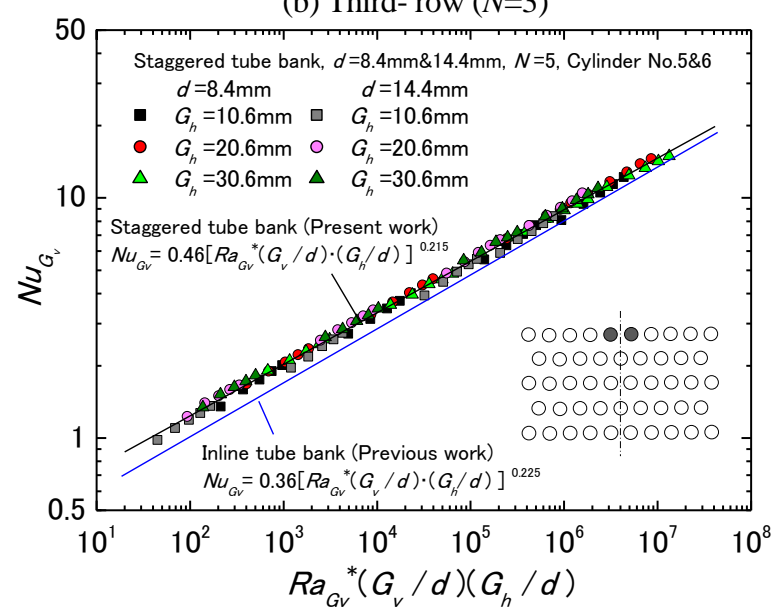

(d) Fifth- row $(N=5)$

Fig.14 Rearrangements of Nusselt numbers for the central cylinders of the horizontal rows $N=2-5$ in the staggered tube banks, where $N u_{G v}$ based on the vertical gaps $G_{v}$ are plotted with the parameter $\left[R a_{G v}{ }^{*}\left(G_{v} / d\right)\left(G_{h} / d\right)\right]$. The plots gather around the black solid lines in the figures, indicating that the parameter $\left[R a_{G v}{ }^{*}\left(G_{v} / d\right)\left(G_{h} / d\right)\right]$ well correlates the Nusselt numbers $N u_{G v}$ regardless of the diameter $d$, horizontal and vertical gaps $G_{h}, G_{v}$. Moreover, the present plots show higher Nusselt numbers than those for the inline tube banks, which are represented with blue lines.

つぎに本研究では上述の結果を踏まえて，各水平円柱列の中心以外の円柱についても同様な無次元整理を行っ てみた，その一例として，円柱列中心から外側に向かって 3 本目の円柱のヌセルト数 $N u_{G v}$ をパラメータ $\left[R a_{G v}{ }^{*}\left(G_{v}\right.\right.$ $\left./ d)\left(G_{h} / d\right)\right]$ で整理した結果を図 15 に示寸．なお，比較のため前報で得た格子配列バンクの伝熱相関式を図中実線 で示した. この図 15 より, 円柱のヌセルト数 $N u_{G v}$ は, 列中心付近円柱に比べてばらつきは大きくなるものの, バンクのいずれの段でも，図中に示寸直線のまわりにまとまることが分かる．参考までに，これらの直線を式(5) で近似し，式中の係数 $C_{2}$ および指数 $n$ を求めたところ， 2 段目円柱列では $C_{2}=0.81, n=0.18,3$ 段目円柱列では $C_{2}=0.68, n=0.185,4$ 段目円柱列では $C_{2}=0.55, n=0.20,5$ 段目円柱列では $C_{2}=0.43, n=0.215$ となった. また，これら千 鳥配列のヌセルト数 $N u_{G v}$ を格子配列のそれと比較すると， $\left.\left[R a_{G v}{ }^{*}{ } G_{v} / d\right)\left(G_{h} / d\right)\right]$ が小さな領域では，千鳥配列の方 が高い值を示すものの, 両者の差は図 14 に記した列中心付近の円柱に比べて全般的に小さく, とくに下流側円柱 列では差がほとんど認められなくなることが分かる.

なお, 図には示さないが, 円柱列中心から 2 本目の円柱についても, ヌセルト数 $N u_{G v}$ とパラメータ $\left[R a_{G v}{ }^{*}\left(G_{v} / d\right)\left(G_{h}\right.\right.$ $(d)$ ]の間に同様な直線関係が成立し，そのヌセルト数 $N u_{G v}$ は円柱列中心と中心から 3 本目の円柱のほぼ中間の值 を示すことを確認している．一方，これらの円柱よりもさらに列の外側に設置された円柱について同様な無次元 整理を試みたところ, ヌセルト数 $N u_{G v}$ は大きくばらつき, パラメータ $\left[R a_{G v}{ }^{*}\left(G_{v} / d\right)\left(G_{h} / d\right)\right]$ では整理できないことが 
分かった．このようにバンク外側の円柱でデータがばらつく原因であるが，図 6 および図 7 の流れの可視化写真 をみると，バンク中心側の円柱のまわりにはバンク下方から侵入し，上流側円柱列で温められたプルームが流れ 込んでいるのに対して，バンク外側の円柱はバンク側方から流入した流れに曝されていることが分かる. このよ うな流れの差異がバンクの外側円柱でヌセルト数がばらつく原因となっていると考えられる.

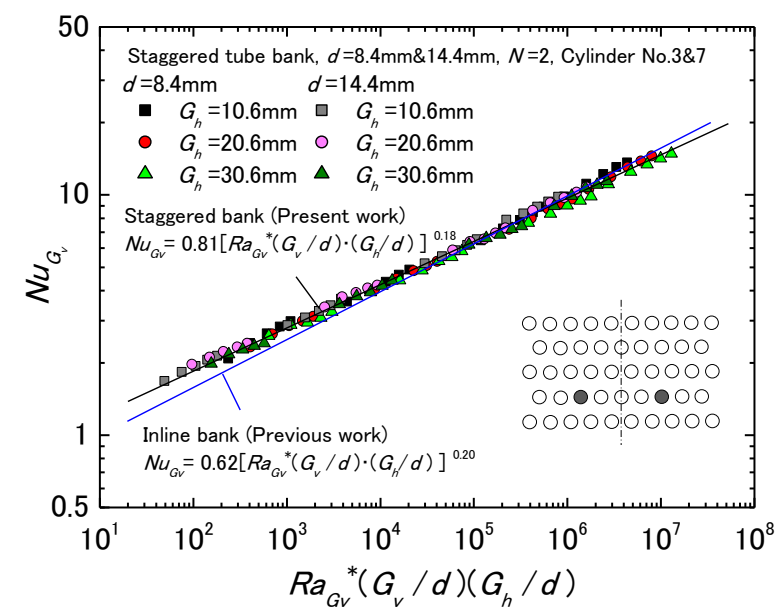

(a) Second-row $(N=2)$

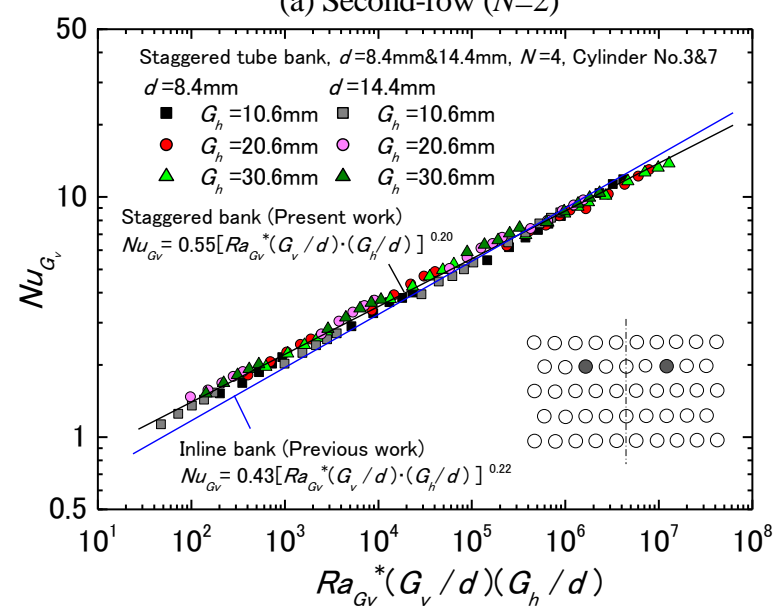

(c) Fourth-row $(N=4)$

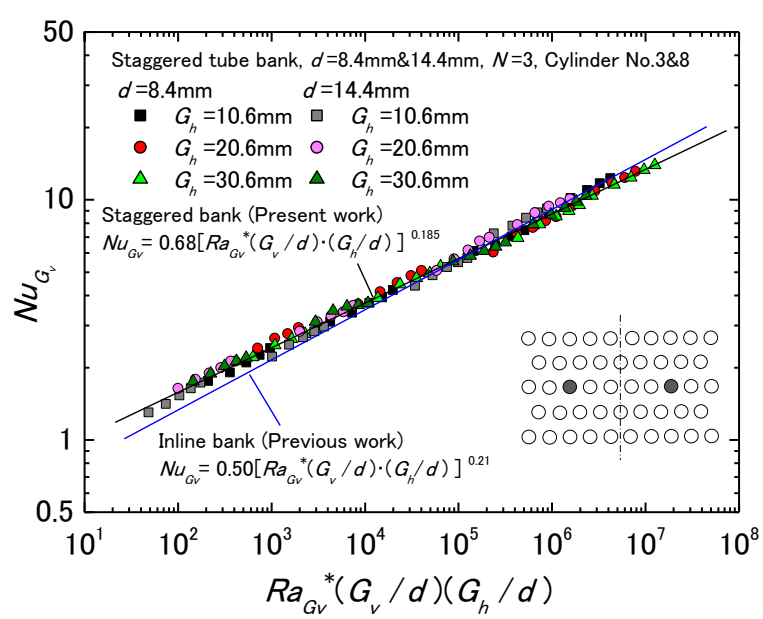

(b) Third-row $(N=3)$

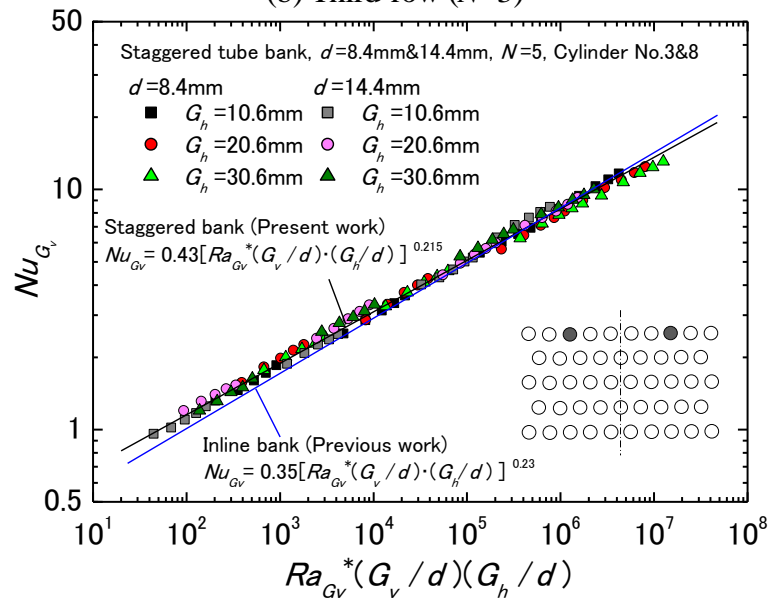

(d) Fifth-row $(N=5)$

Fig.15 Rearrangements of Nusselt numbers for the off-centered cylinders of the horizontal rows $N=2-5$ in the staggered tube banks, where $N u_{G v}$ are plotted with the parameter $\left[R a_{G v}{ }^{*}\left(G_{v} / d\right)\left(G_{h} / d\right)\right]$. The plots gather around the black solid lines in those figures, indicating that their Nusselt numbers can be correlated also with the parameter $\left[R a_{G v}{ }^{*}\left(G_{v} / d\right)\left(G_{h} / d\right)\right]$.

\section{4. 結 言}

本研究は，水平な加熱円柱を一定な水平および垂直方向間隔 $G_{h}, G_{v}$ で千鳥状に配置したチューブバンクについ て，バンクまわりに生じる自然対流の流動と伝熱を流れの可視化および伝熱実験により調べたものである．実験 は常温の空気を試験流体とし，バンクを構成する全ての円柱を同一の熱流束 $q_{w}=60-250 \mathrm{~W} / \mathrm{m}^{2}$ で加熱した. 試験 円柱には直径の異なる 2 種類の円柱 $(d=8.4,14.4 \mathrm{~mm})$ を用い, 円柱の水平方向間隔 $G_{h}$ を 10.6, 20.6 および $30.6 \mathrm{~mm} の$ 3 種類，垂直方向間隔 $G_{v}$ を 5.6, 10.6, 20.6 および $30.6 \mathrm{~mm} の 4$ 種類，それぞれ独立に変化させた．なお，これらの 実験で実現された円柱直径基準の修正レイリー数 $R a_{d}{ }^{*}$ は 800-3×10 , 円柱の水平, 垂直方向間隔 $G_{b}, G_{v}$ と直径 $d$ との比 $\left(G_{h} / d\right),\left(G_{v} / d\right)$ は, $\left(G_{h} / d\right)=0.736-3.64,\left(G_{v} / d\right)=0.389-3.64$ である. 本研究では, 10 本および 9 本の円柱か らなる水平円柱列を垂直方向に 5 段千鳥状に配置したチューブバンクを対象として, まずバンク内に生じる流れ を煙により可視化してみた．また可視化と同じ条件で，バンク内に設置された全ての円柱のヌセルト数 $N u_{d}$ を測 定した. その結果,

(1) バンク最下段円柱列から吐出された煙はバンク中心線に向かって寄り集まる様子が観察された. また, 水平円 柱列のヌセルト数はバンクの下流側に向かって単調に低下していくこと,バンクの 2 段目以降に設置された円 
柱列のヌセルト数 $N u_{d}$ は, 列中心付近で高く, 外側に向かうにつれて緩やかに低下した後, 増加に転じること が分かった.

この結果を踏まえて, つぎに本研究では水平および垂直方向の円柱間隔 $G_{h}, G_{v}$ がバンク内に設置された各水平 円柱列のヌセルト数 $N u_{d}$ にどのような影響を及ぼすか調べてみた，その結果，

(2) 最下段円柱列のヌセルト数 $N u_{d}$ は, 垂直方向の円柱間隔 $G_{v}$ の夕に依存して変化し, 間隔 $G_{v}$ が狭くなるにつれ て高くなること. 一方，2段目以降の円柱列のヌセルト数は，水平および垂直両方向の円柱間隔 $G_{h}, G_{v}$ に依存 して変化することが分かった。

さらに, 本研究ではこれら千鳥配列バンク内に設置された円柱のヌセルト数を, 前報の格子配列バンクと同様 な無次元パラメータを用いて整理してみた。 その結果,

(3) 垂直方向の円柱間隔 $G_{v}$ を又セルト数および修正レイリー数の代表長さにとれば，千鳥配列バンク最下段円柱 列のヌセルト数 $N u_{G v}\left(=h_{m} \cdot G_{v} / \lambda\right)$ は, 修正レイリー数 $R a_{G v}{ }^{*}\left(=g \beta q_{w} G_{v}{ }^{4} / \lambda \alpha v\right)$ と $\left(G_{v} / d\right)^{2}$ との積からなる無次元パラ メータ $\left[R a_{G v}{ }^{*}\left(G_{v} / d\right)^{2}\right]$ で整理でき，両者の相関式は前報の格子配列バンクのそれと一致することが分かった.

(4) 一方, 千鳥配列バンクの 2 段目以降に設置された水平円柱列の外側 2 本を除く円柱のヌセルト数 $N u_{G v}$ は, 前 報の格子配列バンクと同様, 修正レイリー数 $R a_{G v}{ }^{*}$ と $\left(G_{h} / d\right)$ および $\left(G_{v} / d\right)$ の積からなる無次元パラメータ $\left[R a_{G v}{ }^{*}\left(G_{v} / d\right)\left(G_{h} / d\right)\right]$ で整理できることが分かった。 また，これらヌセルト数 $N u_{G v}$ を格子配列バンクのそれと比 較したところ，千鳥配列バンクのヌセルト数の方が高い值を示し，その差はとくに $\left[R a_{G v}{ }^{*}\left(G_{v} / d\right)\left(G_{h} / d\right)\right]$ が小さ な領域で顕著となることを示した.

これら本研究で得られた一連の結果は, チューブバンクの伝熱・流動の基礎的な理解に役立つだけでなく, チ ユーブバンク型熱交換器, ピンフィン型ヒートシンクをはじめとする様々な伝熱機器の熱設計や伝熱性能向上に 有益な情報を提供すると考えられる.

\section{謝 辞}

本研究を遂行するに当たり，JSPS 科研費 $15 K 05823$ の助成を受けた．また，実験を遂行するに当たり本学大学 院生 堀友輔君の協力を得た. ここに記して謝意を表する.

\section{文献}

Bejan, A., Fowler, A. J. and Stanescu, G., The optimal spacing between horizontal cylinders in a fixed volume cooled by natural convection, International Journal of Heat and Mass Transfer, Vol.15, No.11(1995), pp.2047-2055.

服部直三, 川島隆二, 山田尚央, 片岡健, 水平円柱群の自然対流熱伝達, 日本機械学会論文集 B 編, Vol.59, No.566 (1993), pp.3216-3223.

服部直三，相原栄世，千鳥配列を有する水平円柱群からの自然対流熱伝達，日本機械学会論文集 B編，Vol.61， No.592(1995), pp.4551-4515.

北村健三，光石暁彦，鈴木孝司，格子配列された水平加熱円柱群の自然対流熱伝達，日本機械学会論文集，Vol.84, No.857(2018), DOI:10.1299/transjsme.17-00410.

\section{References}

Bejan, A., Fowler, A. J. and Stanescu, G., The optimal spacing between horizontal cylinders in a fixed volume cooled by natural convection, International Journal of Heat and Mass Transfer, Vol.15, No.11(1995), pp.2047-2055.

Hattori, N., Kawashima, R., Yamada, T. and Kataoka, K., Natural convection heat transfer from horizontal circular cylinder bank to air, Transactions of the Japan Society of Mechanical Engineers, Series B, Vol.59, No.566 (1993), pp. 3216-3223 (in Japanese).

Hattori, N. and Aihara, E., Natural-convection heat transfer from horizontal circular cylinders in staggered arrangement to air, Transactions of the Japan Society of Mechanical Engineers, Series B, Vol.61, No.592 (1995), pp.4511-4515 (in Japanese).

Kitamura, K., Mitsuishi, M. and Suzuki, T., Natural convective heat transfer from in-line banks of horizontal cylinders, Transactions of the JSME (in Japanese), Vol.84, No.857 (2018), DOI:10.1299/transjsme.17-00410. 